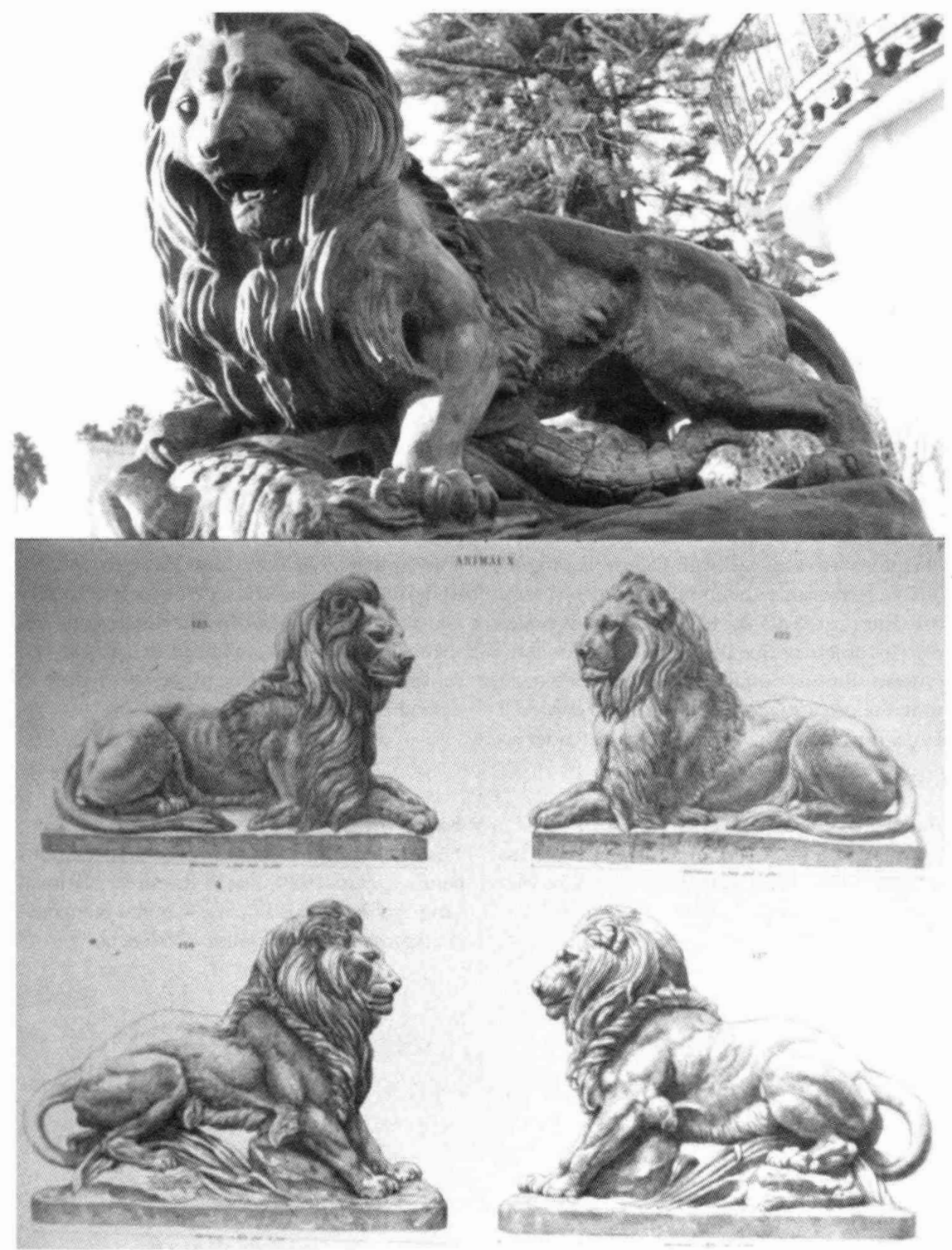




\section{Rogelio Jiménez Marce}

Maestro en Historia por el Instituto Mora. Estudiante de doctorado en el Centro de Investigaciones y Estudios Superiores en Antropología Social. Sus temas de interés son la historia cultural, la historia intelectual y la historiografía. Entre sus publicaciones destacan "La creación de una genealogía liberal", Historias, núm. 51, eneroabril de 2002; "La construcción de las ideas sobre la raza en algunos pensadores mexicanos de la segunda mitad del siglo xIx" Secuencia, núm. 59, mayo-agosto de 2004; La pasión por la polémica. El debate sobre la bistoria en la época de Francisco Bulnes, Instituto Mora, México, 2003.

\section{Resumen}

En el artículo se analiza la novela Héctor de David Ramírez (Jorge Gram). Esta novela buscaba defender la licitud de la lucha que los cristeros habían realizado contra las acciones "antirreligiosas" del gobierno revolucionario encabezado por Plutarco Elías Calles. En el artículo se hace un balance de la literatura cristera y se pregunta por el lugar que ocupa la novela de Ramírez en el ámbito literario nacional. La novela proporciona elementos para entender la percepción que Ramírez tenía sobre la sociedad y cuáles eran los objetivos que perseguía el movimiento cristero. Ramírez estaba convencido de que el movimiento armado había fracasado debido a la negligencia de la sociedad para defender su creencia religiosa.

\section{Palabras clave:}

Novela histórica, literatura cristera, conflicto religioso 1926-1929, David Ramírez, Liga Nacional de la Defensa Religiosa, relación IglesiaEstado, José María González y Valencia.

\section{Abstract}

This article analyzes the novel Héctor by David Ramírez (Jorge Gram). This novel sought to defend the legality of the struggle the Cristeros had waged against the "anti-religious" actions of the revolutionary government led by Plutarco Elias Calles. The article attempts to weigh up Cristero literature and examines the place occupied by Ramírez' novel in the national literary sphere. The novel provides elements for understanding Ramírez's perception of society and the goals pursued by the Cristero movement. Ramírez was convinced that the armed movement had failed due to society's failure to defend its religious beliefs.

\section{Key words:}

Historical novel, Cristero literature, religious conflict 1926-1929, David Ramírez, National League of Religious Defense, Church-State relations, José María González y Valencia.

Fecha de recepción:

marzo de 2004

Fecha de aceptación:

noviembre de 2004 


\title{
"Una pluma frente a una espada" o de cómo escribir una novela para justificar una rebelión: Héctor de David Ramírez (Jorge Gram)
}

\author{
Rogelio Jiménez Marce
}

Para Ángeles y Cornelio

Que viva mi Cristo

Que viva mi rey

Que impere doquiera

Triunfante su ley

¿Viva Cristo Rey!

Viva

¡Viva Cristo Rey!

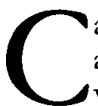

antaba la muchedumbre que poco a poco llenaba los espacios de aquel viejo edificio. Testigo mudo del paso de las acciones armadas de la revolución, mismas que destruyeron su esplendor. Un esplendor que se había ido para no volver jamás. La gente cantaba de manera fervorosa, había pasado mucho tiempo desde la última vez que oyeron una misa. La mayoría de ellos había pasado varios días encerrados en la serranía. La lucha en contra del ejército ameritaba grandes sacrificios. Y ellos estaban dispuestos a hacerlos para defender lo que más amaban: su religión. La multitud se postró de rodillas cuando vieron que se acercaba el sacerdote al improvisado altar. Dos manojos de flores, un cuadro con la figura del santo Niño de Atocha, un gran crucifijo, dos velas y dos sábanas blancas constituían todo el adorno. No importaba la pobreza del lugar, ni lo raquítico del mobiliario. Lo único que le interesaba a la gente reunida en ese lugar era escuchar la palabra de Dios. Palabra vedada por la intransigencia. El sacerdote inició la misa, cada uno de los presentes se arrodilló. Las manos al frente en actitud de oración. En esta postura permanecieron todo el tiempo que duró la celebración eucarística. Cuando el sacerdote alzó la hostia, las oraciones y el llanto se entrecruzaron.

Aquellos hombres y mujeres renovaron su pacto frente a Dios. Ni los sufrimientos, ni las carencias, ni el temor a la muerte los harían desistir de su lucha. La "causa santa" tendría que triunfar. Dios no permitiría lo contrario. Su causa era la justa, con ellos estaba la razón. El gobierno caería por atentar en contra de los sentimientos sagrados del pueblo. Acabada la misa los hombres recogieron sus sombreros, subieron a sus caballos e iniciaron la marcha de nueva cuenta hacia la sierra. La lucha los esperaba, pero iban contentos, habían conseguido la bendición de Dios. Ya nada los perturbaría. Dios los acompañaba y los acompañaría hasta el final del camino.' Un camino largo que dejó como recuerdo el afán de un pueblo en defensa de lo que

${ }^{1}$ La fotografía que da pie a esta descripción se encuentra incluida entre las páginas 24 y 25 del libro de Meyer, Cristiada, 1974, t. 2. 
ellos creían. Se puede juzgar si eran fanáticos o no, si fueron engañados o tenían en verdad motivos para rebelarse; pero lo único que no se puede criticar es su persistencia ante la adversidad. De estos hombres, a quien el pueblo y el ejército bautizaron con el nombre de cristeros, nos quedan numerosos testimonios. La fotografía, la prensa de la época, la literatura, las canciones y la oralidad dan cuentan de la enorme veta que constituye este movimiento para la investigación.

En el presente trabajo se hace uso de la literatura, en particular de la novela, como herramienta de trabajo para mostrar la visión que se fincó en torno a la lucha religiosa de los años de 1926 a 1929, mejor conocida como cristiada. Es importante subrayar que la novela de tema cristero tuvo pocos cultivadores; a lo sumo fueron una docena. Entre ellos destacó el sacerdote David Ramírez, mejor conocido por su seudónimo de Jorge Gram, personaje que escribió una serie de novelas con la intención de mostrar y justificar las acciones armadas que una parte de la sociedad católica emprendió contra el gobierno de Plutarco Elías Calles. Lo que nos interesa de la obra novelística de Ramírez, en específico de su novela llamada Héctor, consiste, en primera instancia, en mostrar los argumentos de los que se valió para fundamentar y demostrar la validez del movimiento armado. En el pensamiento de Ramírez se advierte que el conflicto religioso de 1926 a 1929 no fue algo espontáneo, por el contrario, tenía marcadas raíces históricas que, de manera inevitable, llevarían a la confrontación directa entre la Iglesia y el Estado. Por otra parte, se realizará un balance general de la literatura que en sus diversos géneros se ha ocupado del movimiento cristero.
Además, se pondrá especial énfasis en mostrar cuál es el ámbito al que pertenece el tipo de novela que escribió David Ramírez. ¿Es valido afirmar que su producción literaria se inserta en la esfera de la novela histórica o pertenece a otro subgénero? La pregunta resulta pertinente por una razón: en los últimos años, los especialistas de la teoría literaria han debatido en torno a los fundamentos en los que se apoya la novela histórica. El debate no sólo se ha circunscrito a la relación entre la historia y la ficción, sino que se ha planteado cuáles son los principios en los que se apoya la inclusión de la novela dentro de la historia. Como último punto se analizará la función que Ramírez le otorgaba a cada uno de los personajes ficticios presentes en su relato. Aspecto de suma importancia, puesto que en cada una de sus creaciones se adivina una propuesta de tipo arquetípico. Es decir, su intención al proponer un tipo de personaje residía en mostrar el modelo de hombre y mujer virtuoso; pero también mostraba el lado contrario de la moneda, el hombre y la mujer ruines y traidores a la causa.

\section{LOS CRISTEROS EN EI ÁMBITO LITERARIO MEXICANO}

La producción literaria que concentra su atención en el movimiento cristero se ubica dentro de dos géneros: la novela y el cuento. ${ }^{2}$ Por el momento no nos ocu-

2 Algunos de los cuentos son "Don Goyo" del Doctor Atl; "La muerte del coronel Florencio Estrada" de Antonio Estrada; "Voy a cantar un corrido" y "El corrido de Demetrio Montaño" de Francisco Rojas González; "Media carta de amor" de Heriberto Navarrete; "La batalla de la cruz" de Ramón Rubín; "Dios 
paremos del cuento, nuestra atención sólo se centrará en la novela, puesto que ella es la que ha alcanzado un mayor grado de difusión entre los lectores. Si algo se puede decir de la narrativa de tema cristero $^{3}$ es que nació con un doble pecado original: pecó tanto por su origen histórico como por su contenido y estilo. La mayoría de los estudiosos de la literatura mexicana le habían negado, hasta últimas fechas, un papel preponderante en la producción artística mexicana, y si se la llegaba a mencionar, era para registrar la existencia de esas producciones, pero no para analizarlas. En buena medida, la negación se justificaba porque se la comparaba con las obras literarias de la revolución mexicana, mismas que habían legado grandes novelas y grandes autores. En contraste, los relatos de tema cristero carecían de una producción notable, tanto en lo que se refiere a las obras como a los creadores. ${ }^{4} \mathrm{La}$ poca atención que se le prestaba a la novelística de tema cristero

en la Tierra" de José Revueltas; "Federico Reyes, el cristero" de Rafael Bernal; "La noche que lo dejaron solo" de Juan Rulfo; "Luto en primavera" de Alfredo Leal Cortés; "Que del cielo venga tu premio... iY no tarde, desgraciado!" de Manuel Caldera; "El peso de la palabra" de Luis Sandoval Godoy; "El emperador de los asirios" de José Emilio Pacheco; "Don Nicho Hernández" de Guillermo Chao Ebergenyi.

${ }^{3}$ Para los fines de este estudio utilizaremos este término, acuñado por Agustín Vaca, porque consideramos que funciona como medio de integración de las distintas propuestas que en torno a esta novela existen.

${ }^{4}$ Vaca, Silencios, 1998, pp. 74, 79; Valenzuela, Historia, 1961, p. 546. El jesuita Alberto Valenzuela, un notable defensor de la novela de tema cristero, tuvo que reconocer que este tipo de narrativa carecía de los atributos de la novela revolucionaria. Sobre todo en lo que respecta a la adecuación de la realidad. fue enmendada, en 1951, por Manuel Pedro González, quien en su Trayectoria de la novela mexicana realizó el primer intento para ubicar a la novela de tema cristero dentro de la narrativa nacional. ${ }^{5}$

A partir de ese momento, los especialistas encontraron notables dificultades para situar las narraciones de tema cristero dentro de un ámbito definido. Esta imprecisión inicial ha derivado en la formulación de cuatro posiciones respecto al problema: una parte de los estudiosos optó por reunir los relatos dentro del término de novela cristera; en tanto que otra decidió llamarla novela contrarrevolucionaria; un tercer grupo la ubicó como un apéndice de la literatura de la revolución, y una cuarta posición es más abierta, puesto que concilia todas las manifestaciones artísticas en el término de novela de tema cristero. En el primer caso, se comprendía en este género novelístico sólo a los autores que participaron de manera directa en los sucesos, los que escribieron a favor de él y los que se identificaban con los ideales cristeros. Con esto se limitaban las posibilidades de incorporar las novelas producidas en años posteriores y por autores ajenos al evento o con una posición diferente respecto al movimiento."

5 Véanse Vaca, Silencios, 1998, pp. 71-72; Olivera, Literatura, 1970, pp. 9 y 235.

"Valenzuela, Historia, 1961, pp. 536, 544-546. Un ejemplo de ello es la opinión que Valenzuela ex. terna acerca de Pensativa y de La Virgen de los cristero. Para el jesuita, estas novelas tienen su mayor defecto en que los autores no retrataron a los cristeros como Dios manda. Valenzuela estaba convencido de que la única forma como se podría lograr una descripción fidedigna era convivir con los cristeros y, de esta forma, se lograría penetrat en su mística. Otro ejemplo lo constituye Cristo Rey o la persecución de Alberto Quiroz. Esta novela le mereció su crítica mordaz, pues el au- 
En el segundo caso se justificaba esta acepción al advertir que este tipo de narraciva significaba una clara manifestación de la lucha propagandística en contra de los logros de la revolución. Así, cualquier novela que se ubicara en el periodo de lucha religiosa y que mostrara sus simpatías hacia ella era catalogada de este modo.

Desde esta perspectiva, cualquier novela que se manifestara en contra del movimiento cristero era asimilada a la novela de la revolución. El punto central se resumía en quién le hacía propaganda a quién. ${ }^{7}$ En lo que respecta al tercer punto, se mostraba que la narrativa que relataba las acciones de los cristeros no era precisamente una exaltación de la guerra religiosa, al contrario, por el tipo de temática desarrollada se inscribía dentro del género novelístico de la revolución, aunque de menor calidad literaria. El fundamento en el que se basaban para incorporarla como un apéndice de la novela de la revolución residía en que, al fin y al cabo, los novelistas de la cristiada ocu-

tor no "vivió ni revivió aquella tragedia". Valenzuela sólo incluía como novelas de tema cristero a todos aquellos relatos que reproducían testimonios y a los que escribieron los participantes.

${ }^{7}$ Dessau, Novela, 1972, pp. 44, 72 y 293; Magaña, Novela, 1965, t. 2, pp. 181 y 184; Meyer, Cristiada, 1973, t. 1, p. 139; Vaca, Silencios, 1998, p. 77. Dessau, Brushwood, Magaña y Meyer coinciden en caracterizar el movimiento cristero como un movimiento contrarrevolucionario. En lo que respecta a la novela, Dessau, Max Aub y Magaña insisten en su carácter contrarrevolucionario, porque en ella, dicen los autores, no se encontraba una exigencia de "tipo social" y servía más bien como un tipo de propaganda que influía en "un numeroso público pequeñoburgués y campesino de tendencias religiosas", a través de la explotación de la "ingenua credulidad" de esos hombres. paban algunas de las técnicas que empleaban los escritores de la novela de la revolución. Y, en cierta medida, se concebía a este movimiento como un epílogo de las acciones revolucionarias, lo que fortalecía el argumento para incluir a los relatos de temática cristera dentro de la literatura de la revolución. ${ }^{8}$ A diferencia de las tres anteriores, la novela de tema cristero busca ser un medio incluyente de las distintas manifestaciones literarias que giran en torno a este suceso. De tal forma busca incorporar todos los relatos - sin importar tiempo ni filiación- que se hayan producido sobre la rebelión católica y que tenían la aspiración de escribir desde esta forma literaria.

Lo novedoso de esta visión reside en que no busca hacer una crítica radical a las técnicas novelísticas, sino que es un intento de abrir el horizonte de posibilidades que ofrecen las novelas. ' La última propuesta es la más adecuada para entender en su totalidad la novela de tema cristero. Desde esta perspectiva, se puede señalar que existe un ciclo dentro de ésta que inició, en 1930, con la publicación de la novela Héctor de David Ramírez (Jorge Gram), y que todavía da frutos como lo muestra la novela $D e$ Los Altos de Guillermo Chao Ebergenyi, que se editó en 1991. A lo largo de estos 60 años, se publicó un buen número de novelas cuya calidad ha sido cuestionada, pero que son representativas del interés que a algunos autores les provocó este fenómeno histórico, ya sea para defenderlo, para atacarlo o como un ejercicio de escritura e imaginación. La aparición de Héctor de David

${ }^{8}$ Brushwood, México, 1973, p. 364; Morton, Novelistas, 1949, p. 236.

9 Vaca, Silencios, 1998, p. 71. 
Ramírez dio pie para que se editaran otras obras que describían el conflicto religioso. En 1931 se publicó Alma mexicana de Jaime Rand (Jesús Medina Ascencio). En 1934 salieron de las imprentas La Virgen de los cristeros de Fernando Robles y Jabel de David Ramírez. En 1935, Jorge Gram presentó La guerra sintética.

De 1937 datan Ay Jalisco... no te rajes. La guerra santa de Aurelio Robles Castillo, Los cristeros. La guerra santa de Los Altos de José Guadalupe de Anda y ; Viva Cristo Rey! de Vereo Guzmán. En 1938 se publicó El poder y la gloria de Graham Greene. Para el año de 1941 se editó Nayar de Miguel Ángel Menéndez. En tanto que en 1942 se publicó Los bragados de José Guadalupe de Anda. 1945 fue el año en el que hizo su aparición Pensativa de Jesús Goytortúa Santos, novela que ganó en 1944 el premio Lanz Duret. 1946 nos legó $E l$ santo que asesinó de Fernando Robles. Mientras que en 1952 Alberto Quiroz presentó Cristo Rey o la persecución, y Entre las patas de los caballos de Luis Rivero del Val. En 1961 se publicó Rescoldo de Antonio Estrada. En 1963 se editó Los recuerdos del porvenir de Elena Garro. En 1966 apareció José Trigo de Fernando del Paso y en 1991 De Los Altos de Guillermo Chao Ebergenyi. Al tomar en conjunto a la novela de tema cristero se aprecian particularidades interesantes. En primer lugar, el inicio y el fin del ciclo se caracterizan por tener novelas que se apartan de lo establecido. Uno lo hizo en el ámbito político, el otro en el literario. La novela de Ramírez apareció un año después de los arreglos de la paz entre el gobierno de Emilio Portes Gil y la Iglesia católica mexicana.

Con esta acción, Ramírez rompió casi de manera inmediata el mutismo que se guardaba respecto del conflicto, situación que le acarrearía serios conflictos con las autoridades civiles y eclesiásticas. En cambio, el caso de los últimos libros es diferente. En ellos se aprecian las cualidades estilísticas y la propuesta de una nueva forma de escribir novela, más que su contenido histórico. El debate sobre lo que se afirma ha pasado a un segundo plano. Por otra parte, se aprecia que la mayoría de éstas se ubica dentro del subgénero de novela de tesis, sobre todo las de la primera época (1930-1945), pues este medio les sirve a los autores para externar su opinión sobre el conflicto y sus consecuencias inmediatas. En términos generales, la novela de tema cristero -a excepción claro está de las novelas de Garro, Del Paso y Chao- ha recibido críticas severas debido a su limitado estilo literario. Lo menos que se dice de ellas es que carecen de una propuesta interesante y que sus carencias obligan al lector a alejarse de su lectura. ${ }^{10}$ A pesar de ello, cuatro novelas merecieron el paulatino reconocimiento de los estudiosos: Pensativa de Jesús Goytortúa, Los cristeros y Los bragados de José Guadalupe de Anda, y Rescoldo de Antonio Estrada.

Este reconocimiento se debe a que en estas novelas no existe una actitud propagandística del movimiento cristero, al contrario se percibe en ellas un sentimiento de protesta social. En Rescoldo y Pensativa se muestra la intención de los autores de ser imparciales ante el evento que rela-

${ }^{10}$ Meyer y Doñan, Antología, 1993, pp. 15-16; Magaña, Novela, 1964, t. 1, pp. 181 y 184. Para Meyer y Doñan, la novela de tema cristero no consiguió reflejar la intensidad dramática de este capítulo de la historia de México. Las novelas no aportan ninguna alternativa estilística y sólo se dedicaron a difundir cuestiones ideológicas. 


\section{SECUENCIG}
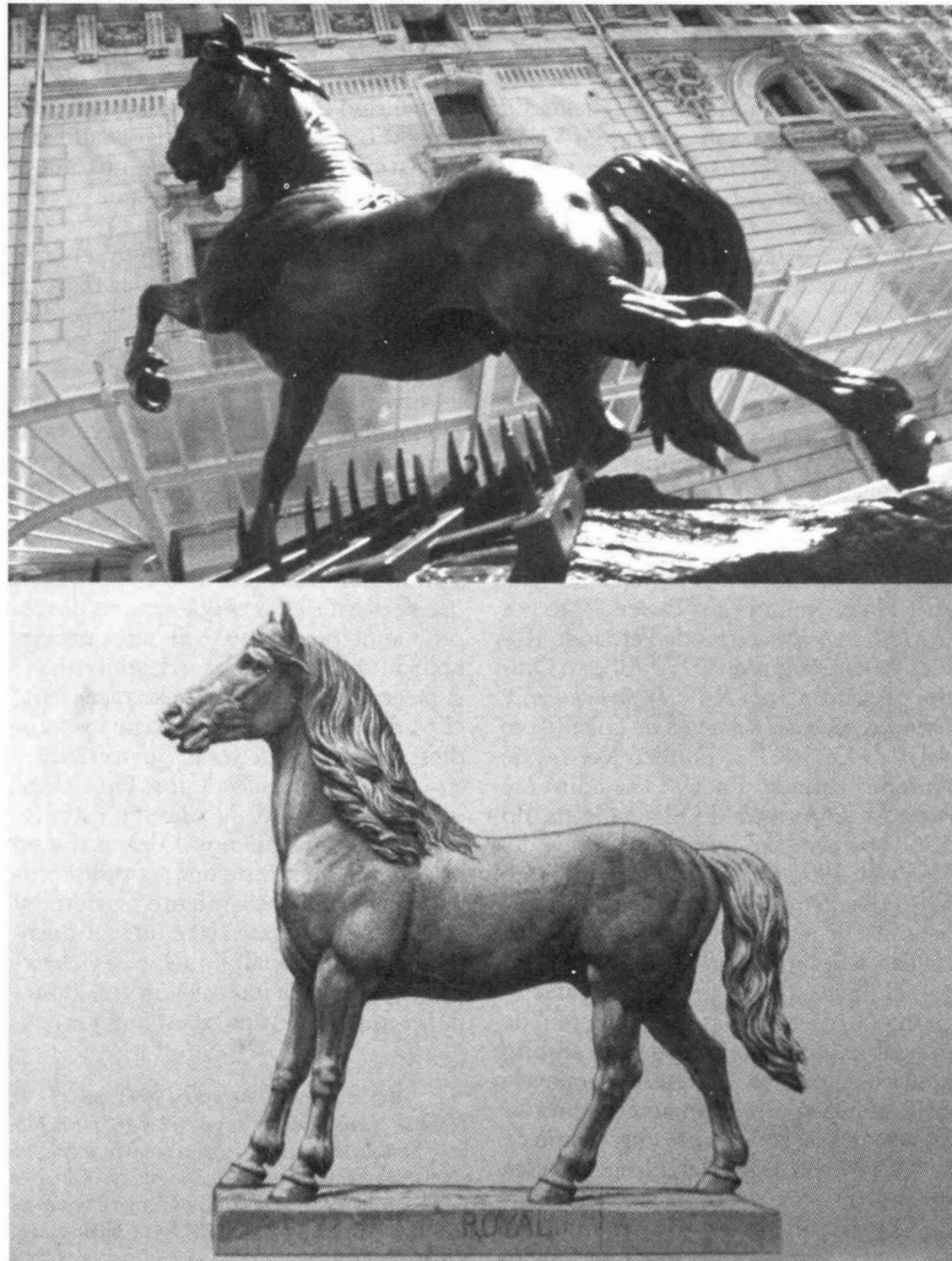
tan. Una de las virtudes de estas dos novelas es que señalan los principales resabios que dejó la lucha religiosa. En la visión de los autores se adivinaba que, a pesar de que se realizaron los acuerdos de paz, ello no fue un impedimento para que el odio y la pasión siguieran omnipresentes. En tanto que las novelas de José Guadalupe de Anda narraban las acciones de la lucha cristera e intentaban deslindar responsabilidades. El conflicto armado no había sido provocado por el pueblo, sino que era un producto de la disputa generada entre la jerarquía eclesiástica y la gubernamental. De Anda manifestaba que el pueblo era el único perjudicado por la guerra, pues tuvo que sufrir las atrocidades de uno y otro bandos. Un problema que aqueja a la novela de tema cristero es el prejuicio inicial con el que se la aborda. Agustín Vaca señala que ni los historiadores ni los críticos literarios se acercan a ella para estudiarla.

Mientras los historiadores descartan este tipo de literatura con el argumento de que no es una fuente confiable de información de primera mano, los críticos literarios la acusan de tener escaso valor artístico, por su tendencia a mostrar observaciones de tipo propagandístico, más que aserciones de carácter literario. Las acusaciones no se pueden negar. Es cierto que algunas novelas de tema cristero tienen enormes fallas de composición y que su contenido, en ciertos casos, deforma los acontecimientos a su favor; pero ese argumento no se puede extender para todas las novelas. La generalización de esta idea ha provocado que la novela de tema cristero sea un subgénero poco apreciado. Es por esta razón que para comprender lo que nos ofrece este tipo de novelística, es necesario enfocar su estudio desde una perspectiva más amplia. Al encasillar a una novela dentro de un parámetro preestablecido se restringen las posibilidades de comprensión de la misma. Por ello es necesario expandir el horizonte de expectativas respecto a ésta. Más allá de hacer el tradicional ejercicio de comparación con la realidad para comprobar si lo descrito es cierto o no, se debe observar qué es lo que la novela nos ofrece en sí. El discurso contenido en ella puede ser más rico de lo que uno se imagina.

Es un hecho que la novela contribuye a crear imaginarios sociales, a ofrecer figuras de identidad (identificación) que fijan representaciones del mundo y, sobre todo, transmite un discurso social representativo del momento de producción. ${ }^{11}$ Eso sin mencionar que nos permite comprender el pensamiento del autor, pues es evidente que un escritor no redacta por el simple hecho de hacerlo. Atrás de él se encuentra una posición ante el suceso que relata; trata de exponer su verdad, una verdad mediatizada por las circunstancias que lo rodean y que es preciso desentrañar. Un asunto que se ha pasado por alto es que la novela de tema cristero ha contribuido a fincar gran parte del conocimiento popular acerca de este suceso histórico. Agustín Vaca señala que la amplia difusión de la que han gozado las novelas ha encontrado un ámbito de mayor audiencia que la que han dispuesto las obras de carácter académico. ${ }^{12}$ Un ejemplo patente de esta aseveración es la novela Héctor de David G. Ramírez.

"Sefchovich, México, 1987, pp. 95-96 y 1.25 ; Brushwood, México, 1973, p. 389; Vaca, Silencios, 1998, pp. 78, 81, 90-91 y 93 .

${ }^{12}$ Vaca, Silencios, 1998, p. 88. 


\section{Un sacerdote novelista}

que nació en la ciudad de Oaxaca en el año de 1890 . Realizó sus primeros estudios en la ciudad de México. Unos años después decidió dedicarse al sacerdocio. Para ello entró a estudiar al seminario de Durango, donde se ordenó como sacerdote en 1918. Sus méritos académicos le permitieron ganar una beca para estudiar en el Colegio Pío Latinoamericano, ubicado en la ciudad de Roma. Poco después ingresó a la Universidad Gregoriana para estudiar un doctorado en Sociología. En esta universidad se distinguió por sus dotes como orador. En 1924 regresó a México para participar en el Congreso Eucarístico Nacional, el cual se realizó en la ciudad de México durante los primeros días del mes de octubre. La suspensión de este evento, por parte del gobierno de Obregón, le causó una honda impresión, al grado que en su novela Héctor mencionó que la suspensión del congreso representaba un atentado contra la libertad religiosa de los católicos. Unos años después fue nombrado secretario particular del obispo de Durango, el doctor José María González y Valencia, lo que le permitió conocer de cerca la profundidad de los problemas que se gestaban entre la Iglesia y el Estado.

Ramírez acompañó al obispo de Durango en su viaje a Roma, mismo que tenía como misión informar a las autoridades del Vaticano sobre la situación que guardaba la Iglesia católica mexicana. En Roma, Ramírez publicó un folleto que intituló La cuestión de México. Una ley inbumana y un pueblo víctima, en el que realizó una requisitoria de la Ley Calles y, de paso, acusó al gobierno de Estados Unidos de brindar apoyo al presidente
Plutarco Elías Calles. Durante los años del conflicto armado, Ramírez permaneció al lado del obispo de Durango, a quien acompañó en su destierro temporal como producto de los acuerdos de paz en 1929. El resentimiento que guardaba Ramírez, por la forma como se dio término al conflicto, lo confinó a permanecer en el destierro, pese a que el obispo de Durango regresó en 1931. En 1936, el gobierno de Lázaro Cárdenas decidió expulsar a Plutarco Elías Calles. Esta situación permitió que muchos exiliados regresaran al país, Ramírez fue uno de ellos. Las actividades que desarrolló entre el año de su retorno y el año de su muerte (1950) son de poca trascendencia. Se instaló en Durango, lugar en el que se dedicó a escribir algunos libros, poesías y dictó algunas conferencias. ${ }^{13}$

El presbítero David Ramírez fue un personaje secundario en el drama mexicano de los años de 1926 a 1929 , ello no obsta para que su memoria se pierda en el olvido pues a través de

\section{Su producción novelística}

podemos comprender a un hombre que, por medio de la escritura, buscaba justificar la rebelión católica. Por esta razón, tuvo serios problemas con la jerarquía eclesiástica y con las autoridades civiles que intentaban a toda costa sofocar el recuerdo de la rebelión. David Ramírez firmó todos sus escritos novelísticos con el seudónimo de Jorge Gram. En total escribió seis novelas: Héctor (1930), Jabel (1934), La guerra sintética (1935), La trin-

${ }^{13}$ Diccionario, 1995 , p. 157 ; Vaca, Silencios, 1998 , p. 93; "Editores", en Ramírez, Héctor, 1953. 
chera sagrada, Rebelde (1955) y He vendido mi túnica (1956). Las dos últimas fueron publicadas post mortem. Sus novelas han provocado una amplia controversia entre los especialistas, misma que se resume en dos posiciones. En la primera se lo acusa de que sus narraciones, sobre todo las tres primeras, tienen la intención de incitar a la rebelión armada. John Brushwood dice que los méritos artísticos de sus obras son pocos, pues su estilo es "primitivo", "agresivo" y "manipulador". Sara Sefchovich afirma que como novelista Ramírez no destaca, pero sí como panfletista y defensor a ultranza del movimiento cristero. Antonio Magaña señala que, para lograr su cometido, Ramírez recurrió a la manipulación de los sentimientos católicos de la masa de la población. Esta manipulación le permitió alcanzar gran éxito con sus novelas. ${ }^{14}$

En tanto que la segunda posición lo muestra como "el autor más importante, desde el punto de vista novelístico, filosófico y de estilo". En esta perspectiva no se pone especial énfasis en mostrar la estructura estilística de la obra, sino el contenido histórico y los argumentos que manejaba en defensa del conflicto. Es por ello que Alicia Olivera afirma que los textos de Ramírez deben ser considerados como libros de consulta histórica más que como novelas. El contenido documental que se encuentra en ellos le otorga veracidad a sus relatos. ${ }^{15}$ Más allá de que se esté de acuerdo con una u otra posición, lo que se debe destacar son las aportacio-

${ }^{14}$ Véase Magaña, Novela, 1964, t. 1, pp. 183 184; Sefchovich, México, 1987, p. 95; Brushwood, México, 1973, p. 367.

15 Olivera, Literatura, 1970, pp. 238-239; Vaca, Silencios, 1998, p. 80. nes que este autor realizó en este género. Su producción novelística se inscribe dentro de la literatura de tesis. A través de sus textos se percibe que la trama ficticia le sirve como un medio para mostrar su opinión respecto a los sucesos que cuenta. Además, y en esto tiene razón Alberto Valenzuela, sus escritos buscan incorporar modelos de conducta social en el pensamiento de los lectores. Lo que incluye a sus novelas, de acuerdo con la clasificación que propone Álvaro Ruiz Abreu, en la categoría de novela moralizante. ${ }^{16}$ Por otra parte, se ha mencionado que sus obras muestran resabios de la novelística decimonónica.

Alicia Olivera ha encontrado elementos del costumbrismo y Adalbert Dessau del romanticismo. ${ }^{17}$ Sin embargo, existe un tercer elemento que no han mencionado los especialistas, la influencia del realismo histórico en la novelística ramiriana. Como es sabido, Héctor, Jabel y La guerra sintética tenían como marco histórico común los problemas religiosos. Las dos primeras describían los sucesos de la primera cristiada, en tanto que la tercera se ubicaba en lo que se ha convenido en llamar la segunda cristiada. Las dos primeras novelas se pueden entender como una sola obra dividida en dos grandes libros. Esto se puede constatar porque Héctor explica

${ }^{16}$ Meyer y Doñan, Antología, 1993, p. 15; Valenzuela, Historia, 1961, p. 536; Vaca, Silencios, 1998, p. 79. Agustín Vaç señala que Álvaro Ruiz Abreu distingue tres categorías de la novela de tema cristero: la moralizante, la anticristera y la imparcial. Menciona que la clasificación es sencilla, pero sirve para efectos prácticos. Sin embargo, considera que lo más adecuado sería clasificar a las novelas de acuerdo con la temática o los recursos estilísticos empleados en ella.

${ }^{17}$ Olivera, Literatura, 1970 , p. 237; Dessau, $\mathrm{No}$ vela, 1972, pp. 291 y 293. 
los inicios del conflicto hasta el incidente del tren en 1927, mientras que Jabel narra los siguientes años hasta el fin del conflicto. La guerra sintética describe los pormenores de la persecución religiosa de 1935 hasta la salida de Calles del país, ocurrida en 1936. En retrospectiva sólo las dos primeras tendrían conjunción interna, pues la tercera se alejaría en tiempo y espacio de las otras dos. Sin embargo, podemos afirmar que las tres novelas constituyen una serie, ya que Ramírez utilizó el recurso de hacer aparecer personajes de una novela en las subsiguientes. Héctor y Consuelo, protagonistas de la primera novela, aparecen en el momento clave del llamado del doctor Magallanes para iniciar "la guerra sintética" ${ }^{18}$

Este recurso utilizado por los novelistas del realismo histórico decimonónico tendía a integrar en un solo universo a los distintos participantes de la novela. Como ejemplo tenemos a Benito Pérez Galdós, quien en sus Episodios nacionales gustaba de hacer aparecer y desaparecer a sus personajes ficticios que eran centrales en otras novelas, y algunos de ellos aparecían en el momento justo del desenlace de la trama. En el caso de Ramírez, la incorporación de Héctor y de Consuelo al llamado del doctor Magallanes servía para demostrar que el principal héroe de la lucha religiosa regresaba para terminar su papel. El papel que se le había asignado a Héctor era liberar a la nación del yugo del gobierno. Si bien el desenlace que propone el autor dista de ser épico, ello no obsta para que apreciemos su ingenio. Sin lugar a dudas, su recurso literario fue inteligente y, con ello, logró cerrar el ciclo de manera adecuada. De las tres novelas de

${ }^{18}$ Ramírez, Guerra, 1935, pp. 200-202.
Ramírez, Héctor es la más conocida y se la ha considerado una de las más representativas de la novela de tema cristero. Ahora bien, ésta

\section{En opinión de sus críticos}

es una novela con pocas virtudes. Según Brushwood, Sara Sefchovich y Adalbert Dessau, la visión que presenta Héctor sobre el movimiento cristero es unilateral. El autor tenía la intención de defender a la Iglesia y a los fieles, por medio de argumentos que mostraran que ellos eran agredidos de manera injusta por las autoridades. De tal forma, crea una oposición entre los buenos (los católicos) y los malos (los callistas) que se reproducirá hasta el cansancio. Los críticos afirman que como novela es de "mala manufactura" y tiende a deformar las acciones armadas de los cristeros, sin cuestionarse las atrocidades que éstos llevaron a cabo. A Ramírez sólo le importaba presentarlos como los héroes de la gesta. Por esta razón, Dessau señala que esta novela sólo se puede calificar como una "propaganda antirrevolucionaria", pues tiende a dirigir las ideas hacia un fin determinado, como lo es el ataque a las instituciones y la incitación a la rebeldía. ${ }^{19}$ Así como se le ha criticado, Héctor también ha encontrado defensores. Entre ellos Alfonso Valenzuela, quien considera que esta novela es extraordinaria, no sólo por su composición artística sino por el mensaje que lleva consigo.

${ }^{19}$ Brushwood, México, 1973, p. 350; Sefchovich, México, 1987, pp. 95-96; Dessau, Novela, 1972, pp. 290, 291 y 293; Vaca, Silencios, 1998, pp. 90, 94-95 y 118; Meyer, Cristiada, 1973, t. 1, p. 404. 
Valenzuela concibe que Héctor fue un medio magnífico para propagar la idea de la licitud de la resistencia armada frente al poder tiránico. Su entusiasmo lo llevó a afirmar que esta obra fue la inspiradora del levantamiento español en contra de los socialistas; afirmación a todas luces exagerada. Los editores de la casa Jus también compartieron ese entusiasmo. En su edición de 1953 señalaron que esta novela, por "su admirable conocimiento del alma y lenguaje populares", merecedora de un lugar entre las obras maestras de la literatura. Una opinión mesurada es la que manifiesta Agustín Vaca, quien piensa que a Héctor "le sobra vigor y agilidad en la acción, y el diálogo se desarrolla con cierta vivacidad", lo que la coloca "entre las novelas más dinámicas y dramáticas de México". Sin embargo, el principal defecto que le encuentra es su visión parcial de los hechos a favor de los católicos y, por supuesto, en contra de las acciones del gobierno. Parcialidad que se comprende, pues Ramírez aparece como el defensor de los derechos que le parecen válidos. ${ }^{20} \mathrm{Al}$ fin y al cabo, Ramírez fue un hombre comprometido con las acciones. No se podía deslindar de las condiciones que lo rodeaban y ello hace que su escritura aparezca como

\section{Una novelística de carácter ideológico}

aspecto que no se debe tomar como falta de objetividad, pues la literatura, por esencia, es formadora de conciencia. Vasconcelos afirmaba que la literatura tenía sus raíces en la libertad; se escribe, entre otras

\footnotetext{
${ }^{20}$ Valenzuela, Historia, 1961 , pp. 540 y 546; Vaca, Silencios, 1998, p. 73.
}

cosas, para hacer justicia. El escritor es un hombre a través del cual se manifiestan las condiciones sociales de su época. Así, es parcial porque busca transmitir un modo de pensar y de percibir las situaciones. ${ }^{21}$ Dessau señala que uno de los problemas más comunes para el análisis de la producción novelística es la poca conexión que existe entre la práctica de la literatura y las discusiones ideológicas de la época. Por lo regular, se ha concebido a la novela como un producto fuera del influjo ideológico. Sin embargo, es la expresión de una realidad y, por lo mismo, constituye un material de estudio de primer orden. En la novela se pueden atrapar elementos que corresponden a una realidad visible e invisible. Es visible por las figuras que recrea, pero es invisible en cuanto producto de un discurso que nunca es inocente, que siempre esconde un último significado. ${ }^{22}$ En ello reside que la escritura de novelas no se pueda entender como una actividad de tendencia netamente literaria. Su inscripción en una sociedad le dicta los parámetros bajo los cuales se debe desenvolver y los mecanismos por medio de los cuales se puede expresar.

María Cristina Pons advierte que los géneros literarios "son portadores de un contenido ideológico" específico. Contenido que, según Françoise Perus, posibilita la producción de determinados efectos de sentido (efectos ideológicos) que contribuyen a la reproducción y transformación de la conciencia social. ${ }^{23}$ La literatu-

${ }^{21}$ Magaña, Novela, 1964, t. 1, pp. 11 y 166; Vasconcelos citado por Carballido, Protagonistas, 1986, p. 21.

${ }^{22}$ Rama, Historia, 1975, p. 44; Barthes, Grado, 1993, pp. 24 y 45; Pons, Memorias, 1996, p. 19.

${ }^{23}$ Pons, Memorias, 1.996 , p. 17; Perus, Realismo, 1995, p. 42. 


\section{SECUENCIG}
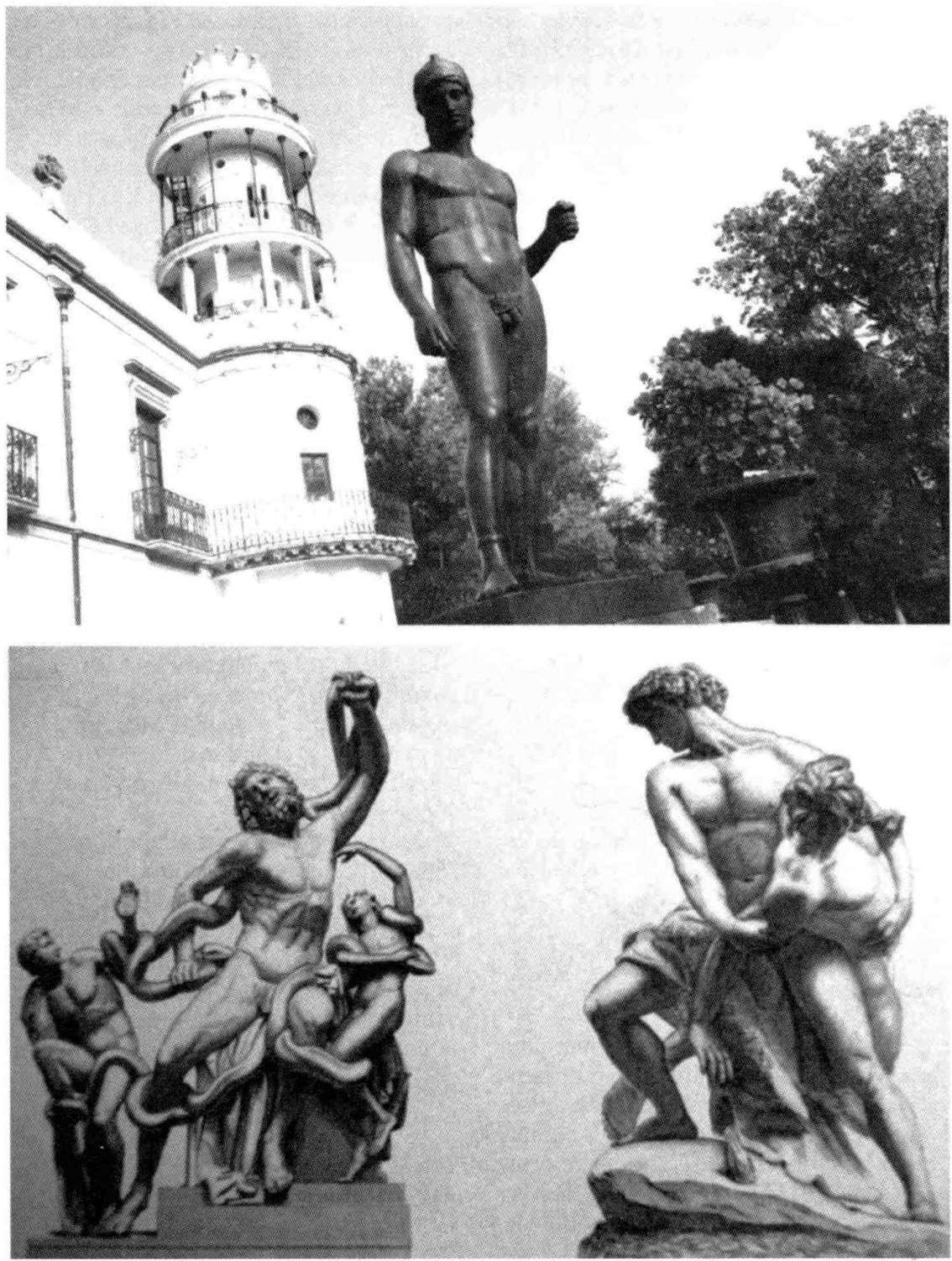
ra no sólo se constituye en un arma crítica contra la realidad, sino que también posibilita el cambio en la actitud al apropiarse de las ilusiones de los lectores. Mediante ella se configurarán nuevos contextos culturales que predispondrán a la audiencia hacia un objetivo determinado, ya sea por medio de marcas, señales o alusiones explícitas o implícitas que tenderán a satisfacer las necesidades del lector. Si el autor consigue hacer creible lo que cuenta, entonces su tarea se cumplirá. El relato resultará eficaz en la medida en que produce creyentes y practicantes de lo que se afirma. Es evidente que a través del discurso se puede manipular a los lectores, para que se adscriban a la posición que se defiende. Todo es cuestión de hacerlo con habilidad. De acuerdo con la clasificación de Noe Jitrik, las novelas históricas de David Ramírez se ubicarían en la categoría de novela histórica "catártica".

Este tipo de novela tiene como principal interés solucionar un problema de carácter inmediato de la relación entre el presente y el pasado referido. Es pertinente aclarar que las novelas históricas que relatan sucesos contemporáneos tienen una orientación política. Los acontecimientos que se describen entran en confrontación directa con el grupo en el poder o tienden a legitimar los discursos instituidos. ${ }^{24}$ Ahora bien, David Ramírez

${ }^{24}$ Pons, Memorias, 1996, pp. 29, 53, 55, 67-68; Certeau, Historia, 1998, p. 59; Romero, "Presentación", 1996, p. 12; Bellenger, Persuasión, 1989, pp. 91 y 112. Los otros dos tipos de novela histórica son la "arqueológica" y la "funcional". La primera se ocupa del estudio de "un contexto referencial desde los medios de que se dispone en un momento muy diferente", mientras que la segunda tiende a mostrar la necesidad de incorporar estudios de periodos que se suponen incompletos o deficientes en el orden intelec- integró su producción novelística al subgénero de la novela histórica. Con ello rompió con los cánones establecidos por los escritores de novela histórica decimonónica, quienes afirmaban que una obra podía ser considerada histórica sólo si mediaba un espacio de tiempo entre el autor y el suceso. Las novelas que contaban sucesos acaecidos en tiempos del autor no podían ser admitidas dentro del subgénero histórico. El alejamiento de Ramírez de la postura tradicional refleja su intención de darle trascendencia al hecho que contaba. En los últimos años se ha discutido cuáles son los criterios que definen a una novela como histórica. De este debate se ha desprendido que no es la distancia entre el momento histórico del autor y el asunto del pasado lo que le otorga la categoría de historicidad a ésta, sino la introducción de personajes y episodios históricos que comparten espacios con los hechos ficticios.

Es decir, lo que hace histórico al pasado es su incorporación dentro de un discurso. La ficción y la historia comparten la misma esencia, las dos serán "reales" en cuanto incluyan personajes que los lectores puedan reconocer como tales. ${ }^{25}$

\section{CONTEXTO HISTÓRICO DE LA NOVELA}

Al iniciar el año de 1929, la situación de los cristeros era, en cierta medida, favorable. Los principales jefes cristeros, Enrique Gorostieta y Jesús Degollado, controlaban varios estados de la república y con-

tual. Es decir, este tipo de novela histótica intenta llenar algún punto oscuro o laguna de la historia.

${ }^{25}$ Pons, Memorias, 1996, pp. 52 y 57; Fernández, Historia, 1998, p. 42. 
taban con un contingente armado que ascendía a cerca de 25000 hombres. Eso sin mencionar los 25000 que se encontraban en pie de lucha a lo largo del país, aunque estos últimos carecían de una organización adecuada y de armamento. A pesar de ello, Gorostieta no se hacía ilusiones sobre la posibilidad de obtener un triunfo rápido. Los ejércitos cristeros tenían seguidores pero carecían de dinero y de municiones. Ante esta situación poco era lo que podían hacer contra el gobierno, quien contaba con armamento y con el apoyo adicional de Estados Unidos. En el periodo comprendido entre febrero y mayo de 1929, los cristeros lanzaron una gran ofensiva contra las tropas del gobierno, misma que culminó con la derrota del ejército y la extensión de su base de acciones en el oeste de México. Como producto de esta victoria, los cristeros controlaron el territorio comprendido entre Durango y Coalcomán, con excepción de las grandes ciudades. Además, consolidaron su influencia en la zona de Zacatecas y del norte de Jalisco. ${ }^{26}$

En respuesta a este movimiento, el gobierno decidió lanzar una gran contraofensiva en mayo dirigida hacia Los Altos de Jalisco, lugar en el que se encontraban 7000 cristeros. Ésta concentró una fuerza de 17000 hombres, integrada en su mayoría por soldados y agraristas, y que tenía la intención de terminar de una vez por todas con el conflicto. A la cabeza de ésta se encontraba Calles, quien dividió sus fuerzas en varios frentes de batalla. Los soldados fueron repartidos entre los generales Saturnino Cedillo, Francisco Figueroa, Lázaro Cárdenas, Maximino Avila Camacho y Eulogio Ortiz. El plan era

\footnotetext{
${ }^{26}$ Meyer, Cristiada, 1973, t. 1, p. 315.
}

ambicioso, pues se pretendía atacar al mismo tiempo los reductos cristeros ubicados en Colima, Michoacán, Zacatecas y Jalisco. Sin embargo, la ofensiva no tuvo consecuencias importantes debido a los escasos fondos de los que se dispuso para llevar a cabo el proyecto. A ello debemos añadir el desgaste propio de la campaña que propició que un buen número de soldados desertara. A eso se debe sumar el fracaso de los grupos agraristas como fuerza complementaria del ejército. Ante el fallido resultado, el ejército retiró sus efectivos instalados en los estados de Jalisco, Colima y Michoacán.

Sin embargo, las autoridades militares decidieron colocar algunos destacamentos para proteger tres de las principales vías de comunicación ferroviaria con el occidente del país: la de Manzanillo a Guadalajara, la de Aguascalientes a Guadalajara y la de Guadalajara a Tepic. Con la desocupación parcial de estos estados, los cristeros consolidaron su dominio en esta zona y en otras del norte como Zacatecas, Durango, Nayarit y Aguascalientes. La situación militar entró en un compás de espera, el cual fue roto sólo por algunas escaramuzas y por la obtención de noticias trascendentes como la muerte del general Gorostieta o la del padre Reyes Vega. Con la desaparición de estos dos dirigentes, Jesús Degollado y el padre Aristeo Mendoza asumieron el mando del movimiento. Mientras esto sucedía en el campo, en la ciudad de México los obispos habían tenido una serie de reuniones con los representantes del gobierno. En junio, los representantes del clero, monseñor Leopoldo Ruiz y Flores y monseñor Pascual Díaz y Barreto, culminaron las negociaciones con el gobierno de Portes Gil. El día 21 del mismo mes se firmaron los 
tratados de paz, lo que dio por concluida la guerra, al menos en el papel. ${ }^{27}$

Los tratados de paz sorprendieron a los cristeros. Ante la negativa de algunos jefes de abandonar la lucha, el clero inició una campaña de desprestigio. Si antes se decía que alimentar a los cristeros era una acción honrosa, ahora se calificaba como un acto pecaminoso. Algunos cristeros proclamaron que ellos no se rendirían, sino que sólo iban a licenciar a sus tropas. Con el fin del conflicto religioso, tanto los obispos como el gobierno mostraton su empeño por echar tierra al asunto. Algunas de las medidas que se tomaron fueron la expresa prohibición de consultar archivos de las organizaciones que participaron en el conflicto y la destrucción de documentos comprometedores. Además, la jerarquía eclesiástica mantuvo la postura de acallar, en la medida de lo posible, la narración de los hechos cristeros. Aurelio Acevedo, un antiguo jefe cristero, calificaba el mutismo de la Iglesia respecto al movimiento cristero como "la conjura del silencio". ${ }^{28} \mathrm{El}$ silencio se rompió un año después de la firma de los tratados de paz, con la publicación de la primera novela de tema cristero: Héctor de David Ramírez (Jorge Gram).

\section{LAS RAZONES DE UNA NOVELA}

Vale la pena preguntarse las razones que tuvo David Ramírez para realizar una acción que estaba en contra de las disposiciones eclesiásticas. Es probable que la principal razón que motivó la composición de esta obra resida en la necesidad de buscar un argumento que defendiera

\footnotetext{
${ }^{27}$ Ibid., pp. 292-307 y 322-326.

${ }^{28}$ Vaca, Silencios, 1998, p. 48.
}

su postura política frente al conflicto religioso. Como se mencionó en párrafos anteriores, la posición de apoyo a la causa religiosa que tomó el obispo de Durango, José María González y Valencia, ${ }^{29}$ de quien Ramírez era secretario, propició que, una vez terminadas las acciones armadas, los dos personajes fueran conminados a permanecer fuera del país. Las autoridades eclesiásticas señalaban que esta acción constituía un "destierro temporal" mientras se calmaban las pasiones. En este contexto, la novela se puede concebir como un intento de defensa de las ideas expresadas por el obispo de Durango, uno de los principales defensores de la licitud de la lucha armada. ${ }^{30}$ Ramírez se

${ }^{29}$ Bailey, Viva, 1974, pp. 45, 78 y 293; Barquín, José, 1967, pp. 5-30. José María González y Valenc ia nació el 27 de septiembre de 1884 en Cotija de la Paz, Michoacán. Estudió en el Colegio Pío Latinoamericano en Roma. Después pasó a la Academia de Santo Tomás para estudiar Filosofía. En la Universidad Gregoriana realizó estudios de doctorado solve Teología y Derecho canónico. En 1924 tomó posesión del arzobispado de Durango. González y Valencia destacó por ser un hombre abierto al enfrentamiento. Bailey dice que era menos cauteloso en sus afirmaciones que otros de los obispos debido a su juventud. Śl perteneció al grupo de obispos intransigentes conformado por el arzobispo de Guadalajara, Francisco Orozco y Jiménez; el de Monterrey, Juan de Herrera; el de Huejutla, José de Jesús Manríquez y Zárate; el de Tulancingo, Vicente Castellanos, y el de Tacámbaro, Leopoldo Lara y Torres. Fue nombrado comisionado junto con el obispo de San Luis, Miguel de la Mora, para informar al Vaticano sobre la situación mexicana. Su apoyo abierto y público a la causa cristera le valió su alejamiento respecto a la alta jerarcuia eclesiástica y que, al terminar el conflicto armado, no se le permitiera regresar al país. Castigo que se le levantó en 1931.

${ }^{30}$ Bailey, Viva, 1974, p. 134; Barquín, José, 1967. pp. 26-29; Valenzuela, Historia, 1961, p. 540. Gon- 
propuso reunir, en un solo texto, las opiniones de los obispos y de los principales dirigentes de las organizaciones católicas que también incidían en este argumento. Para él era imprescindible mostrar que el obispo de Durango no era el único que esbozaba estas reflexiones.

Con ello buscaba un punto de apoyo para aminorar el castigo que se les infligió. Además, en la búsqueda de argumentos de apoyo a su causa, recurrió a la autoridad de las doctrinas bíblicas, de los doctores de la Iglesia y de pensadores católicos con la intención de demostrar que los razonamientos de los defensores de la lucha armada no se encontraban fuera de contexto, sino que tenían sustento en la autoridad bíblica y teológica. La licitud de la lucha armada no era una invención de fanáticos religiosos, sino, por el contrario, tenía una larga historia de la que podían dar testimonio padres de la Iglesia como san Agustín y santo Tomás. Esa idea también era defendida por los principales teólogos de la época y por algunos de los papas. Si la lucha era lícita, como lo trató de demostrar Ramírez, entonces era justo que las autoridades religiosas hicieran un reconocimiento a aquellos hombres que pelearon en defensa de la religión.

zález y Valencia reunió una comisión de teólogos, entre los cuales se encontraba David Ramírez, para que se encargaran de revisar si tenían validez las disposiciones del artículo 130. La comisión le entregó un dictamen en el que reprobaba los preceptos del artículo. Con base en ello se fundamentó su carta pastoral del 27 de febrero de 1927, misma que le hacía saber a sus feligreses que tras consultar a los principales teólogos de Roma había obtenido la aprobación para que ellos utilizaran las armas sin cargo de conciencia, pues lo hacían para defender a la religión en contra de sus perseguidores.
Por ello, la novela constituye también un homenaje a los participantes en la lucha armada. En el relato de Ramírez se percibe que las constantes agresiones del gobierno de Calles eran soportadas por el pueblo con estoicismo. Sin embargo, el pueblo no podía quedarse impávido ante la intransigencia de las autoridades frente a la Iglesia.

"Tanto va el cántaro al agua que termina por romperse" reza un dicho muy popular, y ello se podía aplicar a la novela escrita por Ramírez. Las agresiones del gobierno contra la Iglesia habían comenzado con la implantación del gobierno liberal y la promulgación de las Leyes de Reforma. La tensa situación entre las dos partes tenía que culminar con una guerra. Para Ramírez, los hombres y las mujeres que participaron en la lucha adquirieron conciencia de su capacidad como pueblo organizado frente a las afrentas del poder. Más allá de la lucha armada, lo que le importaba enseñar era que un pueblo bien organizado podía hacer frente a una autoridad que no respetaba los derechos del pueblo católico. A pesar de las críticas mordaces que se han realizado contra la novela de David Ramírez, ello no obsta para que se pueda afirmar que ha tenido cierto éxito. Hasta el año de 1983 contaba con nueve impresiones. Es interesante constatar que tres de estas ediciones se realizaron fuera del país. En 1934 fue publicada en España; en 1942, en Chile por la editorial Difusión Chilena; y en 1944, en El Salvador por el semanario Criterio. El resto de las ediciones ha sido elaborado por editoriales mexicanas. En lo que respecta al tiraje, se debe mencionar que el número ha sido alto.

Tan sólo en la primera edición realizada en 1930 se sacaron a la luz 5000 li- 
bros; las siguientes impresiones variaron en las cantidades: dos fueron de 3000 números, tres fueron de 2000 y una de 4000 . Estas cantidades comprueban la afirmación de Adalbert Dessau, quien señalaba que Héctor era probablemente una de las novelas mexicanas de la época revolucionaria de mayor difusión. Su alcance sólo era comparable con Los de abajo de Mariano Azuela. Una afirmación un tanto cuanto exagerada, pero que en labios de Dessau resulta interesante, pues este investigador es uno de sus principales críticos. ${ }^{31}$ La novela consta de 300 páginas divididas en 35 capítulos, mismos que conforman a su vez tres grandes apartados. Los espacios que ocupan lo literario y lo histórico, en la obra de David Ramírez, tienen cierto grado de complejidad, porque ocupan tiempos diferentes en momentos distintos. Mientras lo histórico tiene un desenvolvimiento lineal, lo literario se mueve en tiempos retrospectivos. Esta relación hace que la narración genere un conflicto entre lo histórico y lo literario. De hecho, se pueden identificar momentos narrativos en el desarrollo de la novela. En el primero, lo literario sobrepasa a lo histórico. Los acontecimientos históricos sólo sirven de marco para el desenvolvimiento de los personajes ficticios.

En el segundo sólo existe una visión literaria sin tomar en cuenta los aspectos históricos. El relato sólo se construye en torno a las acciones de los personajes. Mientras que en el tercero, Ramírez procuró darle un mismo estatuto a lo histórico y a lo literario. Los personajes ficticios tienen una participación importante en

${ }^{31}$ Dessau, Novela, 1972, p. 293; Vaca, Silencios, 1998, pp. 86-87. el desarrollo de los sucesos históricos, aunque ello no quiere decir que exista una total interrelación entre lo histórico y lo literario. La trama histórica y la literaria se unen, pero conservan sus propias dinámicas narrativas. Es importante señalar que la narración de Ramírez hace uso de fechas para marcar la trascendencia de algunos eventos históricos y literarios. Sin duda, buscaba con ello darle un mayor grado de verosimilitud a su relato. El uso de las fechas es un recurso que le otorga dinámica a lo que se cuenta; son marcas del lenguaje que apuntan a otorgarle una mayor intensidad al relato, pues advierten al lector sobre la importancia de un acontecimiento. De paso sirven como indicadores del tiempo del relato: si éste es progresivo o si tiende a retroceder. La utilización de este recurso le confrere credibilidad al relato, pues ubica las acciones en un tiempo posible.

Algunos especialistas han señalado que una de las características de la novela histórica es la conjunción de personajes ficticios con personajes reales en un momento dado de la obra; sin embargo, esto no sucede en la obra de Ramírez. Los personajes ficticios tienen pocos vínculos con los personajes reales, quienes sólo aparecen mencionados pero no tienen un desempeño pleno en el desarrollo de los hechos. Este tipo de construcción narrativa recuerda a la novela romántica del siglo XIX. En ella la historia y la ficción ocupaban dos campos de acción diferentes. La historia sólo servía de telón de fondo a los hechos ficticios, tal y como sucede en la novela. El uso de esta estrategia se explica por una razón: ésta pretendía moralizar a través de ejemplos. Dicho lo anterior, es pertinente pasar entonces a describir 


\section{SECUENCIA}

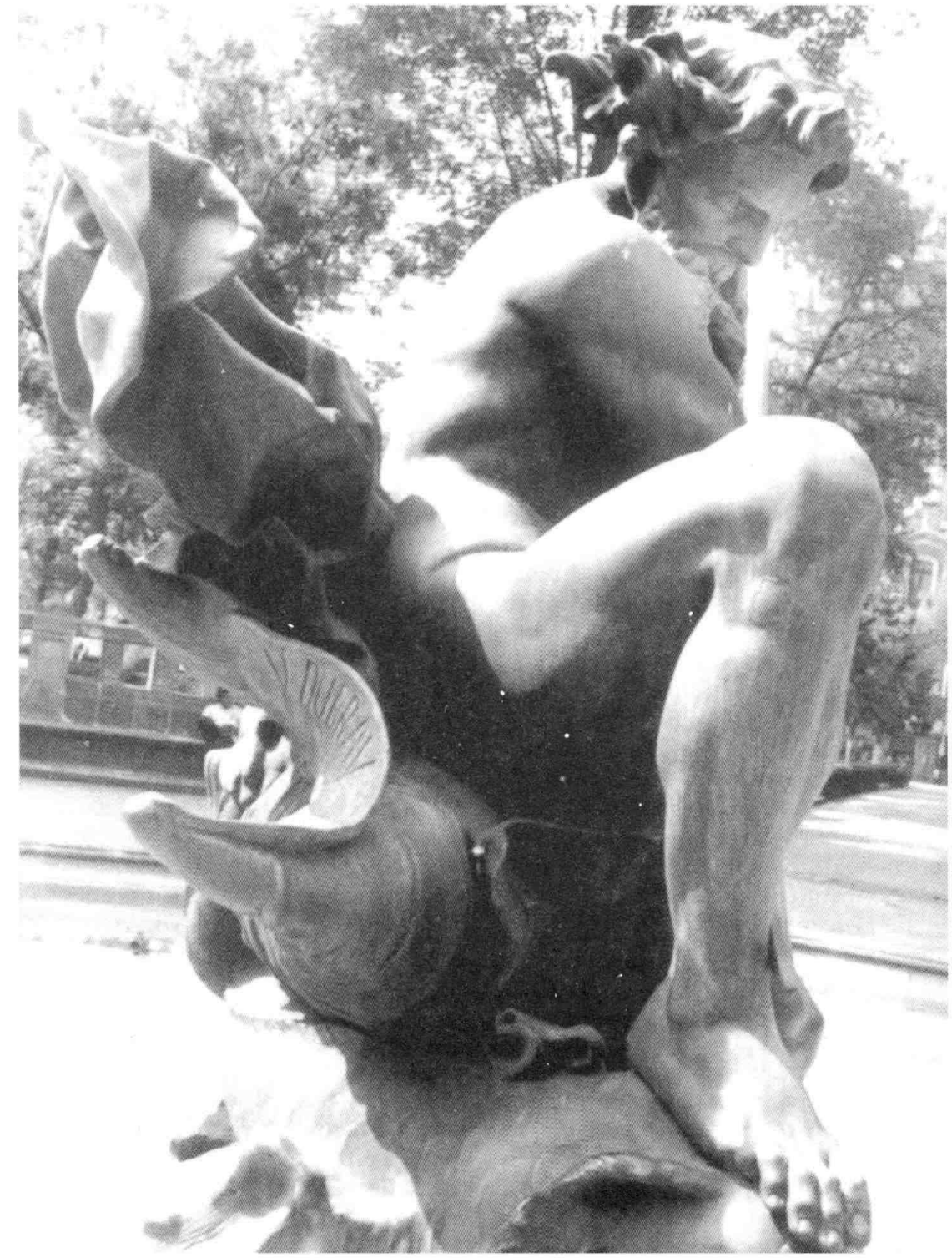




\section{La trama literaria}

de la novela para poder captar los diversos elementos de los que hizo uso Ramírez para llegar a su público. El relato de Ramírez es contado por un narrador diegético; es decir, un narrador que conoce a la perfección los sucesos y deslinda cualquier influencia en ellos. Sin embargo, en algunas partes del texto se confunde al autor con el narrador, lo que propicia la fusión de uno y otro en un mismo narrador. Ramírez se incluye de manera consciente en el relato a través de comentarios $\mathrm{e}$ intervenciones directas dentro de la narración. ${ }^{32}$ La trama de la novela centraba su atención en torno a dos situaciones principales. Por un lado, la tensa situación que se vivía en la ciudad de Zacatecas debido a los conflictos entre la población y las autoridades y, por el otro, la historia de amor entre Héctor y Consuelo, personajes centrales de la obra. Desde el inicio, Ramírez muestra la prepotencia con la que actuaban las autoridades civiles: el gobernador había ordenado que el ejército desalojara el edificio en el que se albergaban las madres teresianas. Con una hábil estrategia de la madre Francisca, quien fungía como procuradora del colegio teresiano, se logró ganar tiempo para que ellas se organizaran e impidieran el desalojo.

Al esparcirse la noticia del desalojo, la población se congregó frente al edificio para impedir la expulsión. La aparición de Consuelo, protagonista central de la novela, le dio nuevos bríos a las monjas para defenderse. Ésta entendió que la situación era comprometida, por lo que pidió la ayuda de la Asociación Católica

32 Vaca, Silencios, 1998, p. 95. de la Juventud Mexicana (ACJM) y de la Unión de Damas Católicas, quienes buscarían trasladar a las monjas a un lugar seguro. La situación se volvió tensa cuando Consuelo y las monjas le hicieron una broma pesada al general Ortuzar. Éste decidió sacar a las monjas sin miramientos, para ello movilizó a dos compañías del ejército. La prepotencia mostrada por los soldados provocó que la gente reunida en las afueras del edificio se rebelara. Algunos muchachos de la ACJM dispararon sobre los soldados y éstos les respondieron, lo que degeneró en una batalla campal que dejó como saldo un muerto y algunos heridos. Entre los heridos se encontraba Soledad Martínez, la madre de Héctor, el otro personaje central de la obra. Éste se enteró del triste acontecimiento mientras trabajaba. Abandonó sus quehaceres y se dirigió a su casa para enterarse del estado de salud de su madre. Al verla muy lastimada reaccionó con furia y juró vengarse de los que le hicieron daño.

En ese momento conoció a Consuelo, quien había acompañado a la herida a su casa. Los dos quedaron impresionados, pero no hicieron evidente su amor debido a que existían distancias económicas y sociales que los separaban. Héctor y Consuelo habían prometido lograr la libertad religiosa, por lo tanto, los dos tuvieron una destacada participación en sus respectivas organizaciones. Él era miembro de la Liga Nacional de la Defensa Religiosa y ella era la secretaria general de la Unión Profesional de Empleadas Católicas. La posición social de Consuelo le proporcionaba un mayor ascendiente entre los zacatecanos. Ante el anuncio de la Ley Calles, los católicos zacatecanos se organizaron con mayor ahínco. Héctor y Consuelo participaron activamente en la prepara- 
ción del boicot económico, una medida que fue apoyada por la mayoría de la población. Ante el éxito de éste, el gobierno buscó culpables. Uno de ellos fue Héctor, a quien mandaron a la penitenciaria de la ciudad de México acusado de ser el principal instigador del boicot. En este lugar se le ofreció la oportunidad de abandonar la lucha. Sin embargo, las autoridades no lograron vencer la entereza del personaje, que salió airoso de la prueba. Mientras tanto en Zacatecas, Consuelo logró reunir la cantidad de dinero que se pedía por la libertad del protagonista.

Tras su liberación, Héctor se puso en contacto con los miembros de la Liga Nacional de la ciudad de México, quienes le ordenaron que promoviera la causa armada en los estados del norte del país. La decisión estaba tomada. Éste se levantaría en armas para defender la religión. Les confesó esta idea a su madre y a Consuelo, quienes lo animaron a llevarla a cabo. Buscó ayuda espiritual y material con un sacerdote timorato que le hizo ver que su causa no triunfaría. Aunque se alejó desilusionado, tuvo la suerte de encontrarse con el sacerdote Gabriel Arce, quien lo impulsó a seguir con su proyecto. Al llamado de Héctor para levantarse en armas respondió un buen número de hombres, pero la carencia de armas los obligó a asaltar un cuartel militar. La intrepidez de los atacantes aunada a la ineptitud de los soldados ayudó a que obtuvieran la victoria: pertrechados se encaminaron al monte para esperar el paso de los militares que se dirigían a Fresnillo. Su estratégica posición les permitió acabar con ellos. Las victorias que consiguió Héctor lo convirtieron en un enemigo a vencer. A pesar de la estrecha vigilancia que había en la ciudad de Zacatecas, las autoridades no lo- graron evitar que Héctor entrara a la ciudad para casarse con Consuelo.

Al descubrirse la presencia de éste se montó un cerco militar, del cual logró escapar gracias a su habilidad. Sin embargo, el padre Gabriel Arce, Consuelo, la tía de Consuelo, la mamá de Héctor y uno de sus amigos - Juan- no corrieron con la misma suerte. Ellos fueron apresados y los mandaron a la cárcel. El padre Arce y Juan se negaron a revelar el paradero de Héctor por lo que los condenaron a muerte. Todos los presos salieron en el ferrocarril que se dirigía a Guadalajara: los hombres para morir en el camino, las mujeres para ser encerradas en la cárcel. En el tren iba armamento destinado a establecer un centro de operaciones en esa ciudad. Los cristeros, al mando de Héctor, se enteraron de ello y decidieron atacarlo. Existe una cierta indecisión por parte del protagonista cuando se enteró de que en el ferrocarril iban su mamá y Consuelo. Aquél comprendió que la causa era más importante y emprendió el ataque al ferrocarril. Gracias a una hábil maniobra, uno de los cristeros logró desenganchar el carro en el que viajaban los presos. Con ello la historia tuvo un final feliz. Se logró el cometido de salvarlos y se consiguió el armamento necesario para seguir la lucha. ${ }^{33}$ En la narración de Ramírez destaca la for-

${ }^{33}$ Meyer, Cristiada, 1973, t. 1, pp. 87, 173; Dooley, Cristeros, 1976, p. 1.24; Rius, Méjico, 1960, pp. 245-246; Gutiérrez, Historia, 1993, pp. 35-36; Dessau, Novela, 1972, pp. 290-291; Sefchovich, México, 1987, pp. 95-96. El 19 de abril de 1927 se produjo el asalto al tren de Guadalajara, este evento ha generado diversas posiciones respecto al hecho. Dooley señala que las versiones que corrían respecto a la ferocidad de los cristeros es discutible, pero no le queda la menor duda de que el asalto produjo un gran impacto. Rius minimiza los hechos sangrientos 
ma como analiza la participación que tuvieron los personajes en la movilización social. Ellos son

\section{Los actores}

del drama que conmueve a la sociedad. Resulta del todo interesante que el autor recurra a personajes representativos para juzgar la participación de los distintos grupos de la sociedad. Héctor, Consuelo, la madre Francisca, el padre Martín, los Soberón, el padre Gabriel Arce y el capitán Caravantes son personajes ficticios que representan las cualidades o defectos del grupo al que pertenecen. Ellos no van a determinar las acciones sino que se subordinan al devenir histórico. En el relato se advierte que Ramírez buscaba describir lo inmediato de la realidad social que percibía. Lo que muestra, en palabras de Lucien Goldmann, su poca fuerza creativa como escritor de ficción. ${ }^{34} \mathrm{La}$ sociedad descrita en las páginas de Héctor presenta un cuadro en el que existen los buenos, los malos y los feos. Entre los buenos encontramos a

\section{Consuelo y las mujeres}

Si un rasgo destaca en la novela de tema cristero es la participación que se le otor-

al declarar que sólo se quemaron cadáveres. En tanto que Adalbert Dessau, Jean Meyer y Sara Sefchovich señalan que los sucesos culminaron con una terrible matanza. La opinión de Sara Sefchovich es importante porque señala que Héctor sirvió como una justificación del ataque al tren.

${ }^{34}$ Pons, Memorias, 1996 , p. 58; Vaca, Silencios, 1998, p. 95; Magaña, Novela, t. 1, 1964, p. 13; Rama, Historia, 1975 , p. 30. ga a las mujeres en el desarrollo de los sucesos. Ellas ocupan un papel preponderante en las acciones: son las encargadas de conseguir parque, de curar a los enfermos y de pasar información secreta. El rasgo más llamativo de esta narrativa es la inclusión de la mujer como combatiente; pero no una más, sino alguien que dirige a las tropas. Tan sólo pensemos en Gabriela Infante, la protagonista de Pensativa, una mujer férrea que dirigía con soltura a sus soldados. El paso de la subordinación a la colaboración es el rasgo esencial que diferencia a la novela de tema cristero de la novela de la revolución. Mientras en la primera se percibe la admiración a la mujer, en la segunda se encuentra una oposición entre el hombre dominador y la mujer dominada. ${ }^{35}$ Héctor constituye un homenaje a las mujeres que participaron en el movimiento. Desde las más pobres hasta las más ricas, desde las más educadas hasta las analfabetas, casi todas participaron en la rebelión. Casi todas, porque algunas no compartían los ideales. Así, se crea una primera dicotomía: por un lado, se encuentran las emprendedoras, encarnadas en Consuelo y, por el otro, las apáticas como Leonor y Luz Soberón, que desperdiciaban su vida en diversiones vanas.

En el caso de Consuelo se la describe como una mujer extraordinaria, rica pero no vana, bella pero no presuntuosa. Su inteligencia, su recato, sus creencias bien arraigadas, su distinción, su discreción, su virtuosismo, su gallardía y, sobre todo,

35 Vaca, Silencios, 1998, p. 92; Meyer, Cristiada, 1973 , t. 1, p. 69 . La admiración y el respeto hacia la mujer se observa también en otros planos. Como ejemplo tenemos El Plan de Los Altos en el que se afirmaba que ella "ha sido el agente poderoso y decidido en los momentos de la lucha". 
su amor a los débiles la hacen aparecer como una mujer diferente, alejada de la gente de su nivel social. Aunada a sus cualidades también se encuentra la de tener conciencia de su papel en la sociedad, por lo tanto es una mujer dedicada en cuerpo y alma a la acción social. Su participación como secretaria general de la Unión Profesional de Empleadas Católicas de Zacatecas le permite tener acceso a todas las organizaciones que pelean por la defensa de la religión, como se observa en el caso del desalojo del colegio teresiano, pues una llamada suya bastó para movilizar a toda la ciudad. Consuelo conjuga todos los atributos femeninos, mas no es la única mujer virtuosa en el relato. La madre Francisca, que tiene un papel secundario en la narración, muestra la firmeza de decisión frente a la adversidad. Ella es la encargada de detener en primera instancia a los soldados, y su inteligencia le permite salir avante en la confrontación. Al grado de que sus enemigos, en este caso el capitán Caravantes, reconocen su valer. Soledad Martínez, la madre de Héctor, también desempeña un papel importante en la trama. Su serenidad en el momento clave permitió que Héctor partiera a la guerra sin temor. El sacrificio de la madre era imprescindible para liberar a la religión. Fuera de estos tres ejemplos puntuales, la fuerza de las mujeres radicaba en su capacidad de organización. Ramírez destaca que las agrupaciones femeninas estaban ramificadas en toda la ciudad, de tal forma que constituían una verdadera fuerza de ataque, que las hacía temibles frente al gobierno por su capacidad de decisión y destreza que las caracterizaba. Como un ejemplo del grado de organización que podían alcanzar las mujeres, Ramírez muestra a la Unión
Profesional de Empleadas Católicas y a las Brigadas Femeninas Santa Juana de Arco. ${ }^{36}$ La primera cumplía el papel de espionaje en la ciudad, mientras que la segunda era una agrupación destinada a ayudar con armas, parque, medicinas y ropa para los combatientes. La valentía de la mujer es uno de los atributos que se tratan de resaltar a lo largo del texto. En uno de los diálogos, una de ellas afirma que ellas no se asustan ante la adversidad.

Las mujeres eran capaces de tomar la iniciativa y le demostraban a los hombres timoratos cómo se debían hacer las cosas. Ante la falta de iniciativa del hombre, la mujer era la que respondía al aletargamiento. Ellas eran las encargadas de convencer a los hombres de que tenían que pelear por la religión. Así, su papel no sólo consistió en el apoyo moral sino también en el material. Este último de mayor importancia. Ramírez decía que las mujeres no combatieron con armas pero sus acciones sirvieron para mantener vivo el ideal. Por esta razón, el autor pensaba que la mujer mexicana había obtenido un timbre de gloria, mismo que deberían imitar las demás mujeres católicas del mundo, a fin de que se salvara una religión que se identificaba con los intereses de la civilización. Consuelo y las mujeres no eran las únicas buenas de la película, pues

${ }^{36}$ González, Matar, 2001, pp. 135-136. Las brigadas femeninas se formaron en junio de 1927. La primera brigada se constituyó en Zapopan por un grupo de mujeres que pertenecían a la Unión de Empleadas Católicas. El 4 de marzo de 1928 se conformó el Consejo Supremo de las Brigadas Femeninas en la ciudad de México. Celia Gómez fue nombrada jefe supremo de las Brigadas Femeninas. Ella había sido designada jefe del movimiento feminista católico por Anacleto González Flores. 


\section{Héctor y los bombres}

desempeñan un papel que crecía conforme se abatía la adversidad sobre la masa de la población. Es significativo que los hombres que definen la trama aparecen hasta la segunda parte de la narración. Antes de ello, no existen. La atención se concentra en las acciones de las mujeres en contra de los soldados. La aparición de los hombres, sobre todo la de Héctor, precedía a los desmanes provocados por los enemigos de la causa. Antes de que el protagonista se convirtiera en cristero fue llamado por su madre que se encontraba herida. La escena, en cierta forma, evoca la necesidad de un caudillo cuando la patria lo necesita. Un caudillo que guíe las acciones hacia buen término. David Ramírez señalaba que los caudillos son necesarios cuando la patria yace postrada, ya que éstos aparecen en el momento más desesperado, ellos constituyen un "sol de medianoche". Son hombres que no se abaten ante la adversidad. Por el contrario, crecen hasta alcanzar la fortaleza que los lleva a derrotar al enemigo. Pueden ser derrotados en cuerpo mas no en espíritu. Eso es lo que hace grande a un caudillo. Héctor encarna todos estos ideales. No fue gratuito que se lo incluyera en el momento de mayor desesperación de los católicos. Cuando se necesitaba a alguien que los guiara por la senda de la victoria.

La evocación a Héctor, el héroe troyano, ilustra con mayor énfasis esta necesidad. Ya no era tiempo de discursos, sino de acciones. Alguien debería ser el caudillo y ése iba a ser Héctor. Este héroe, como todo héroe, encarnaba en sí las mayores virtudes: fuerte, valeroso, enérgico, duro, inteligente, resuelto, modesto, distinguido, laborioso, honrado, digno, idea- lista, caritativo y creyente. Resulta interesante que Ramírez haya incluido a este personaje en la clase media citadina. Ello se puede explicar por la indecisión de los ricos ante la situación y el apoyo que las clases medias le otorgaron al movimiento. ${ }^{37} \mathrm{Al}$ contrario de Consuelo, Héctor es un empleado al servicio de un rico poco afecto al movimiento. Su vida está ligada a la Iglesia pero, advertía Gram, no era un hombre fanático. Las circunstancias lo obligaron a levantarse en armas. Circunstancias que también se reflejaban en los hombres que respondieron a su llamado. Las injusticias del gobierno y la persecución religiosa los orillaron a tomar esta resolución. Ramírez pone especial énfasis en mostrar que los hombres que participaron en la lucha armada eran gente honrada, trabajadora y valiente.

No eran bandidos ni fanáticos, sino hombres que "sabían agradecer cuando se les hacía un bien" y que "aguantaban las tropelías con estoicismo". Pero también eran hombres decididos que respondían ante las injusticias del gobierno. El retrato que Ramírez presenta de los hombres muestra que ellos no eran objeto de la manipulación de un grupo. Su levantamiento respondía a situaciones históricas y sociales. En su lema "por mi Cristo, por mi patria, por mi causa" se reivindicaba tanto la libertad religiosa como la lucha por mejorar sus condiciones sociales. Así, el movimiento religioso representaba una válvula de escape de una situación más compleja. Héctor, el caudillo citadino,

${ }^{37}$ Meyer, Cristiada, 1973, t. 1, p. 61; Torres, "Proyecto", 1998, p. 20; Vegas, "Presentación", 1953, p. XXII. Patricia Torres señala que la mayoría de las organizaciones católicas mexicanas se identificaba con las clases medias. 


\section{SECUENCIG}

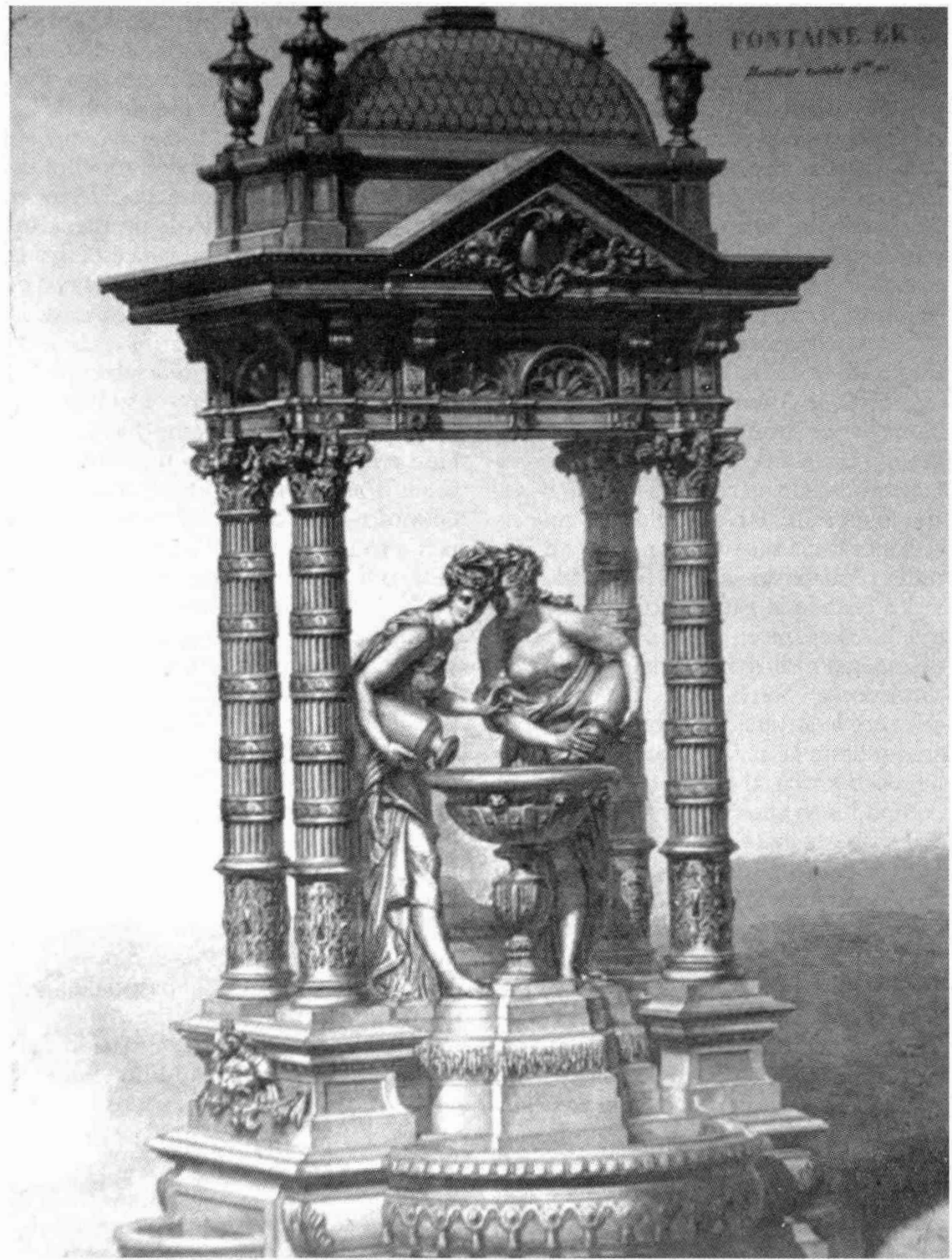


tiene su complemento en Tomás Anzures, el caudillo campirano. Juntos se lanzan al campo de batalla con la intención de liberar al pueblo de la ignominia. La unión del hombre del campo con el de la ciudad revela que los ideales son compartidos. Se podía y se debería luchar hombro a hombro con la bendición de

\section{Los sacerdotes,}

que en la narración de Ramírez se identifican en tres personajes: el padre Martín, el padre Andrés Posada y el padre Gabriel Arce. El primero es un hombre viejo e indeciso que condena el movimiento. El segundo, un hombre maduro que encarna la tesis conservadora de solucionar el conflicto por medios pacíficos; mientras que el tercero refleja la juventud del clero y declara la necesidad de pelear para defender los derechos atropellados. El pensamiento del padre Martín tiene como principio la sumisión. Aconseja que los católicos deberían ser prudentes y callados frente a las disposiciones del gobierno. Este sacerdote condena a la Liga Nacional de la Defensa Religiosa, a la ACJM, a las asociaciones de damas católicas y a los sindicatos católicos porque representaban una agresión en contra del gobierno. ${ }^{38} \mathrm{El}$

${ }^{38}$ Meyer, Cristiada, 1973, t. 1, p. 52; Rius, Porfirio, 1958, pp. 25 y ss. La Asociación Cristiana de la Juventud Mexicana fue fundada por el padre Bergöend en 1913, merced a la fusión de la Liga de Estudiantes Católicos y las Congregaciones Marianas. El primer presidente de esta organización fue René Capistrán Garza. La Liga Nacional de la Defensa Religiosa nació en 1925 como una reacción de los católicos al cisma de la Soledad. Había dos tipos de organizaciones sindicales católicas: la Federación Ar- padre Martín dice que el cristiano no debería ser desobediente. Su misión en la tierra es obedecer y callar. La rebeldía, en el pensamiento del padre Martín, es un pecado que no se debe cometer. El padre Martín muestra que la Iglesia sostenía la doctrina de la paz, de la bondad y de la mansedumbre. De esto se desprende que el católico debe ser humilde y evitar conflictos con la ley del hombre. Para el padre Martín la docilidad solucionaría el problema.

Sin embargo, las circunstancias le enseñaron que esto no era cierto. Cuando una turba asaltó su casa, no recibió la ayuda de nadie. Sus antiguos aliados, representados por el ejército y los ricos, le dieron la espalda en el momento que más los necesitaba. El padre Andrés Posada pensaba que la mejor forma para afrontar las circunstancias que los rodeaban consistía en la moderación. Al igual que el padre Martín predicaba la doctrina de la paz. La Iglesia era una institución cuyo pensamiento sostenía la necesidad de aguantar las agresiones de los enemigos. Todo se podía solucionar por medios pacíficos. Y ésa era la única vía posible. Sin embargo, Posada era un hombre diferente a Martín. Por su convivencia con la gente del campo, comprendía la situación de otro modo. Ramírez menciona que Posada era un sacerdote "bueno como el pan" que oía con pesar las quejas de la gente de su parroquia. Era, al igual que la mayoría de los sacerdotes mexicanos, un

quidiocesana del Trabajo que tenía su sede en el Distrito Federal y la Confederación Nacional Católica del Trabajo presidida por Miguel Palomar y Vizcarra. Las agrupaciones femeninas eran las Damas Católicas, la Congregación Mariana de los Jóvenes y la Adoración Nocturna. 
hombre caritativo y abnegado. Hacía todo lo posible por ayudar a sus feligreses. Valor no le faltaba para enfrentar la arremetida contra la Iglesia, pero por su posición no podía ni debía recurrir a las armas o incitar a sus fieles a hacerlo. Es más, en la medida de lo posible, conminaba a su congregación para evitar que incurrieran en la acción armada.

Aunque Posada difería de esta medida, en el fondo apoyaba la actuación de los cristeros, más por su valentía y tesón que por lo radical de sus acciones. Para Posada era preferible la paz que la guerra. El padre Gabriel Arce era un caso diferente. La educación que recibió en Roma le permitió percibir la situación mexicana desde otro punto de vista. Pensaba que el Estado le había declarado la guerra a la Iglesia. La única solución que restaba era defenderla. Por ello cuando Héctor se entrevistó con él y le planteó su idea de levantarse en armas, más que una condena recibió apoyo. Desde la perspectiva de Ramírez, Arce era el apóstol que transmitía la revelación divina: los hombres deberían luchar por su libertad, cayera quien cayera. Con la unión de estos dos personajes, Ramírez reitera que no habían sido fanáticos, sino hombres rectos los que habían tomado las armas en contra del gobierno. El padre Gabriel Arce era presentado como un prototipo del buen sacerdote: bondadoso, inteligente, con "alma limpia y santa" y, sobre todo, con una robusta vida interior, aspecto que constituía una "fuente inagotable de todos los apostolados heroicos". Este sacerdote difería de los otros en cuanto a la visión del conflicto, pero no por ello los condenaba sino que buscaba comprender las razones por las que ellos rechazaban la solución armada.
Para Arce estaba claro que los sacerdotes no eran cobardes. Su obstinación para legitimar el uso de las armas residía en que no habían realizado un estudio profundo de los hechos, ya sea porque estaban dedicados a otras actividades o porque carecían de la preparación intelectual para hacerlo. Arce manifestaba que la mayor parte de los sacerdotes mexicanos promovía la paz y la paciencia. Es por esta razón que era imposible obtener su conperación. Con esta afirmación, Ramírez buscaba deslindar responsabilidades; no se podía acusar al clero mexicano de ser una institución que buscaba agitar al país. Su cooperación en los sucesos sólo se limitó a la observación y a la reprobación de las acciones de la guerra. Si un grupo de ellos legitimaba el uso de las armas, no lo hacía con el deseo de desestabilizar al país, por el contrario, defendían el derecho de los católicos a proteger sus creencias, ${ }^{39}$ mismas que estaban en peligro de ser erradicadas por las acciones de enemigos tan crueles como

\section{El ejército,}

conformado por hombres que no habían comprendido lo que significaba esta institución. Ramírez pensaba que la milicia no tenía el brillo que la caracterizaba en épocas pasadas. Los soldados de la federación se dedicaban a robar, a asaltar, a violar, a reprimir y a matar, sin que se les interpusiera ninguna fuerza. La voluntad de los militares era la voluntad de la fuerza, no había otra. Su único mérito era

${ }^{39}$ La participación de los sacerdotes en el conflicto se puede ver en Meyer, Cristiada, 1973, t. 1, pp. 30-49. 
destruir con fiereza a sus enemigos. La infamia recorría todos los cuerpos que conformaban a la milicia. Una institución concebida como una pirámide de varios niveles: en la base inferior se encontraban los soldados, en medio aparecían los oficiales, un poco más arriba estaban los generales, y en la cúspide se localizaban el ministro de la Guerra y el presidente Plutarco Elías Calles. Según Ramírez, la degradación del ejército respondía a su origen. De ser una digna organización cuyos atributos eran el pundonor y el valor, y que, además, se dedicaba a la custodia de las instituciones vitales del país, entre ellas la Iglesia, se había transformado en un conglomerado que agrupaba por igual a revolucionarios y a gente humilde e inconsciente, misma que en un principio fue enrolada por Carranza bajo la promesa de reparto de tierras.

Como esto no sucedió, entonces los nuevos soldados se quedaron a servir por el incentivo de dos pesos diarios como pago de haberes. La falta de educación y de disciplina ocasionó que la milicia se envileciera. En general, los militares no hacían nada provechoso. Su único pasatiempo en tiempos de paz era emborracharse, y si había guerra, entonces se convertían en carne de cañón por la poca preparación que recibían. El gran pecado que Ramírez encontraba en estos hombres era su inconsciencia. Ellos conformaban la masa que era movida por las decisiones de los jefes, su voz no se oía. Eso los volvía sujetos dignos de compasión. En el fondo ellos eran tan católicos como cualquiera de los demás hombres. Ramírez pensaba que los oficiales eran hombres carentes de una plena identidad con la corporación. Su incorporación a ella respondía al lugar que ganaron durante las acciones armadas de la revolución, movimiento al que se unieron ya sea por sus convicciones socialistas o para conservar la impunidad de sus delitos. Los oficiales eran "léperos" e "insolentes" tanto con sus subalternos como con la población, lo que ocasionaba que fueran odiados. El ejemplo patente de este tipo de oficial era Pedro Téllez, a quien apodó "Pelotes", oficial sin ideales y dispuesto a reprimir sin esperar orden superior; pero, a su vez, era un hombre que en el fondo ostentaba un ferviente catolicismo.

Los generales que componían el ejército debían su posición a la revolución, por ello a Ramírez no le extrañaba que esos puestos tan importantes fueran ocupados por personas analfabetas. El mayor mérito de estos personajes había sido su habilidad en el campo de batalla. Una vez instalados en el poder dieron rienda suelta a sus ambiciones, ya que la posición que adquirieron les permitía hacer negocios turbios para enriquecerse sin temor a ser encerrados. Al fin y al cabo, ellos representaban a la justicia. Otro rasgo que caracterizaba a estos hombres era la pecaminosa vida que llevaban. Una vida que transcurría en burdeles y cantinas. Aspecto criticable porque ellos representaban las altas esferas del ejército. Al frente de todo el aparato militar se encontraban el ministro de Guerra y el presidente Calles. Personas que tenían un papel diferente, pues ellos representaban al gobierno. La pirámide castrense representaba la fuerza más importante a lo largo y ancho del país, y sus decisiones sobrepasaban las atribuciones del poder judicial y del legislativo, instancias que tenían poca presencia en un país dominado por los soldados que instalados en 


\section{El gobierno}

buscaban oprimir por todos los medios a los ciudadanos. Ramírez estimaba que la administración callista era una minoría vil y ambiciosa que se había impuesto por medio de las armas. Era un gobierno de intrusos que asesinaba sin razón, atormentaba al pueblo y lo vilipendiaba por sus creencias religiosas. Para hacer más ominosa la situación, había dictado una ley que contrariaba todos los principios del país asentados en el catolicismo. Con esta acción el gobierno se convirtió en una tiranía. Desde el punto de vista de Ramírez, un gobernante era establecido por un pueblo libre para que realizara el bien común. Si el dirigente se olvidaba de esta misión y anteponía sus caprichos a los intereses del resto de la población, entonces el gobernante perdía la autoridad que lo legitimaba y se transformaba en un tirano. Cuando la tiranía se extendía a todos los ámbitos sociales y se pasaba de lo particular a lo social los habitantes podían llamar a la resistencia, puesto que la tiranía había sobrepasado los límites de la tolerancia. Sin embargo, los católicos mexicanos sufrían con estoicismo los atropellos, ya que estaban acostumbrados a mostrar la otra mejilla antes de actuar de manera violenta. Su pasividad fue aprovechada por los revolucionarios para apoderarse del poder.

A los católicos sólo les quedó representar el papel de observadores de los desmanes producidos por los políticos. Desmanes que se traducían en comicios que se convertían en comedias montadas por el gobierno, en las cuales el voto no tenía ningún valor. Además de que los representantes del pueblo no cumplían con su labor, pues se subordinaban a los manda- tos de la tiranía. En un ambiente dominado por un pueblo pasivo y tembloroso era lógico que el poder tiránico del gobierno consiguiera sus propósitos. Aunado al miedo del pueblo ante los malos se encuentra el papel de los feos que, en este caso, se encuentran representados por

\section{Los ricos}

quienes se desligaban de su obliga-ción hacia la sociedad. ${ }^{40}$ Ellos tenían el deber moral de aportar el dinero para hacer triunfar la causa. Sin embargo, buscaban no comprometerse en el conflicto. La razón que explicaba este proceder era sencilla: las familias ricas, por lo regular, nadaban entre dos aguas en los momentos históricos graves, dado que buscaban preservar sus intereses a costa de los demás. El retrato de Enrique Soberón tenía la misión de mostrar al millonario prototipo que era acaudalado pero que carecía de alma e ideales. Ello lo llevaba a rechazar cualquier posible ayuda a los cristeros. Soberón pensaba sólo en su beneficio individual antes que en el social. Eso le permitió sobrevivir a la turbulencia de la revolución. La comparación que Ramírez realizó entre el héroe de la novela, Héctor, y Pepe, el hijo de Soberón, resultó poco favorable para el segundo. El vástago del opulento Soberón carecía de cualidades: era un hombre mediocre, majadero, bobo, sin ideales y sin oficio. Al igual que su padre rechazaba y criticaba el movimiento

${ }^{40}$ Meyer, Cristiada, 1973, t. 1, pp. 15, 52-53; Valenzuela, Historia, 1961, p. 517 . Un constante reclamo de la Liga hacia los ricos fue su poca cooperación con el movimiento. 
que buscaba restablecer la libertad religiosa. Tanto padre como hijo representan al católico acaudalado que por su avaricia y egoísmo retrasaba el triunfo de los cristeros. Ese dinero negado había evitado la conquista de la libertad religiosa. Una libertad contra la que se había atentado a lo largo de

\section{La bistoria,}

pues el Estado había impuesto múltiples impedimentos al desarrollo libre de la religión. La revisión histórica de Ramírez tenía como objetivo mostrar que el conflicto religioso no era un producto de las condiciones presentes. Por el contrario, arrastraba una historia larga y tensa entre las partes, en la que se destacaba el anticatolicismo como punto clave de la tensión y la firmeza de los católicos mexicanos para aguantar la presión del Estado "dictatorial". Ramírez situó el inicio del conflicto entre Iglesia y Estado con la implantación de las Leyes de Reforma y la promulgación de la Constitución de 1857. Una carta magna que surgió como producto de las ideas exaltadas de Benito Juárez y por el apoyo que le otorgó Estados Unidos. Para Ramírez, las cláusulas incluidas en la Constitución significaban la ruptura oficial definitiva del Estado con la Iglesia católica. Sin más, se la desplazaba de la vida pública, una vida en la que había destacado como sujeto civilizador. El ataque no sólo se restringía a este rubro. La supresión de las órdenes religiosas, la "laicización" de la vida nacional y la ocupación de los bienes demostraba la dureza de la ofensiva. Sin miramientos se olvidaba la labor que había llevado a cabo la Iglesia durante los siglos anteriores.
Ramírez reconocía que durante la presidencia del general Porfirio Díaz había disminuido la presión contra los católicos. Con la caída de Díaz y el ascenso de Francisco I. Madero a la primera magistratura se vislumbraba un futuro más benévolo, pues durante la administración maderista se había reincorporado a los católicos a la vida política. ${ }^{41}$ Sin embargo, el asesinato de Madero provocó un cambio radical. Carranza imprimió un carácter socialista a la revolución, lo que revitalizó la postura "antirreligiosa" mostrada por Juárez. ${ }^{42}$ El movimiento revolucionario intensificó el ataque a los católicos, debido a la apari-

${ }^{41}$ Meyer, Cristiada, 1974, t. 2, pp. 43-64. La política de conciliación implementada por Díaz ayudó a que la Iglesia se integrara al proyecto de unidad nacional. Díaz logró la unidad de los grupos inconciliables. La política porfiriana preservaba los principios liberales, pero se evitaba su aplicación absoluta. Durante el periodo porfirista, la Iglesia vivió cambios notables: se realizó una reforma interior, hubo una reorganización administrativa, aumentó el número de sacerdotes, consiguió el encuadramiento de los seglares, obtuvo espacios periodísticos y retomó su tarea dentro de la educación. Durante el gobierno de Madero, se fundó el Partido Católico Nacional, proyecto que fue alentado por los obispos y por el mismo presidente. Este partido negaba ser heredero de los conservadores o una organización de carácter clerical.

${ }^{42}$ MacGregor, "Anticlericalismo", 1999, pp. 164-168; Villegas, "Estado", 1999, pp. 193-194; Blancarte, "Contexto", 1999, pp. 252-253. Los constitucionalistas consideraban que la Iglesia era su enemiga, debido a que el episcopado había prestado dinero al gobierno huertista. Josefina MacGregor menciona que este préstamo fue producto de las circunstancias y no una acción decidida por parte de la Iglesia. Ésta pensaba que su acción sería entendida por el grupo que llegara al poder. Los constitucionalistas también tenían cierto recelo contra el Partido Nacional Católico, pues éste participó activamente durante el gobierno huertista. 


\section{SECUENCIG}
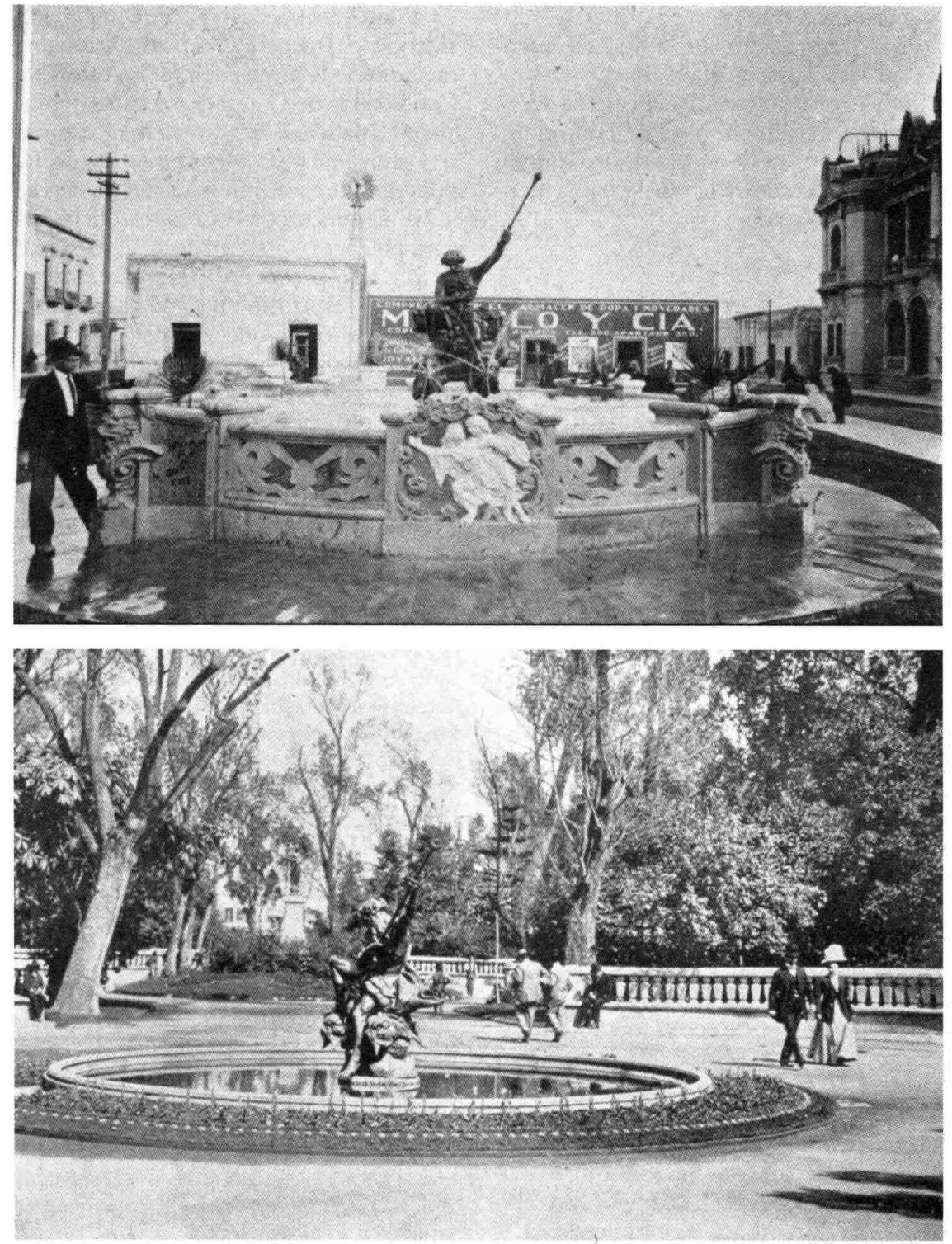
ción de líderes radicales que impusieron su pensamiento en la Constitución de 1917. Así, se renovó el "anticatolicismo" de las Leyes de Reforma. Ramírez pensaba que el objetivo último de la Constitución era el exterminio de la Iglesia. La aparición de "revolucionarios bolcheviques", como Garrido Canabal en Tabasco, $\mathrm{Ma}$ nuel Diéguez en Jalisco, Francisco Múgica en Michoacán, Aristeo Castro en Durango y Plutarco Elías Calles en Sonora, aceleraron la intransigencia en contra de la Iglesia. David Ramírez consideraba que los sucesos del 11 de enero de 1923 ayudaban a entender el rumbo que tomaron los eventos posteriores.

Ese día, las autoridades eclesiásticas, encabezadas por el delegado apostólico monseñor Ernesto Filippi, pusieron la primera piedra del monumento a Cristo Rey en el cerro del Cubilete. En ese lugar, y a petición de los asistentes, realizaron una improvisada misa. El suceso fue interpretado por el gobierno de Obregón como una desobediencia a las leyes por parte de la Iglesia. El presidente tomó la determinación de expulsar al delegado apostólico y de aprehender a los obispos que participaron en el evento. Ello provocó la ruptura de la paz entre las dos partes. La tensa situación entre Iglesia y Estado tendría un nuevo motivo de disputa durante la celebración del Congreso Eucarístico mexicano. El evento se desarrolló en los primeros días del mes de octubre de 1924 y fue cancelado por órdenes del gobierno. ${ }^{43}$

${ }^{43} \mathrm{La}$ expulsión de monseñor Filippi se decretó el 12 de enero de 1923. Ramírez se equivocaba al decir que Filippi fue el que celebró la misa, ésta fue realizada por el obispo de León. El Congreso Eucarístico comenzó el 5 de octubre. El presidente Obregón ordenó el 9 que se suspendiera el evento, pero las
Como respuesta a la ofensiva gubernamental, los católicos fundaron la Liga Nacional de la Defensa Religiosa en 1925, organización que nació, según Ramírez, como fruto de la persecución religiosa. En ella se agrupaba a "los hombres más ilustres y activos del campo de la acción social católica". La organización era de carácter cívico y tenía como prioridad unir a los católicos, instruirlos y dirigirlos para oponerse a sus perseguidores.

Uno de los principales objetivos de la Liga era la búsqueda de la libertad religiosa, misma que se realizaría a través de la modificación de las leyes civiles. El nacimiento de ésta fue aprobado por la jerarquía eclesiástica, por las instituciones sociales y por las congregaciones. Ramírez exageraba su interpretación, pues los obispos no fueron consultados para saber su opinión sobre la creación de esta organización. Los fundadores de la Liga trataban de evitar que los obispos volvieran a prohibir la creación de una organización laica, tal y como había sucedido en noviembre de $1919 .{ }^{44}$ Una tercera ofensa se gestó unos meses después. El 18 febrero de 1925 el sacerdote Joaquín Pérez se proclamó patriarca de la Nueva Iglesia Apostólica Mexicana. Para Ramírez era evidente que el cisma fue apoyado por el gobierno de Calles, quien buscaba debilitar a toda costa a la Iglesia. ${ }^{45}$ También

autoridades religiosas no hicieron caso de la recomendación, lo que ocasionó la furia del mandatario. Así, resulta falsa la versión de Ramírez respecto a este evento. Véase Meyer, Cristiada, 1974, t. 2, pp. 124125 y $1.37-140$.

${ }_{44}$ Ibid., pp. 160-161.

is Para ver con más amplitud estos sucesos véanse Meyer, Cristiada, 1974, t. 2, pp. 51, 123, 138 y 148; Dooley, Cristeros, 1976, pp. 40-48; González, 
señalaba que los católicos habían resistido con estoicismo todos los sufrimientos que el gobierno les había impuesto. Un ejemplo de ello fueron los organismos sindicales católicos, los cuales fueron "vilipendiados" por las autoridades gubernamentales. Asimismo, mencionaba que la Confederación Regional Obrera Mexicana negaba que existieran sindicalizados fuera de su influencia, por lo que los trabajadores católicos no tenían los mismos derechos que aquellos que estaban afiliados a ésta.

El autor decía que era inconcebible que las leyes sólo ampararan a unos y dejaran fuera a los que no compartían las mismas creencias. ${ }^{46}$ Ramírez pensaba que la gota que había derramado el vaso había sido la Ley Penal contra Delitos del Culto Religioso y Disciplina Externa expedida el 14 de junio de 1926. Una ley injusta que aplicaba con todo rigor los artículos constitucionales que eran contrarios a la Iglesia. ${ }^{47}$ Para responder a la ley, la Liga organizó a los católicos para que trabajaran hombro con hombro, tanto hombres como mujeres, en contra de la disposición.

Matar, 2001, p. 44; Torres, "Proyecto", 1998, p. 25. Ramírez no estaba equivocado al sospechar de la injerencia del Estado en el cisma. Este movimiento alcanzó tal fuerza que logró adueñarse de algunas iglesias en Puebla, Veracruz, Tabasco y Oaxaca.

${ }^{46}$ Torres, "Proyecto", 1998, pp. 24-25. La Confederación Nacional Católica del Trabajo se encontraba en constante pugna por el control de los trabajadores. La disputa entre estas dos centrales fue uno de los detonadores del conflicto entre Iglesia y Estado.

${ }^{47} \mathrm{La}$ ley a la que hacía referencia Ramírez era la Ley que Reforma el Código Penal para el Distrito y los Territorios Federales sobre Delitos del Fuero Común y para toda la República sobre Delitos contra la Federación. Esta ley constaba de 33 artículos. Una versión condensada de ella se puede ver en Rius, Mejico, 1961, pp. 59-62.
Ramírez estimaba que la suspensión del culto religioso fue una medida "tibia" por parte de los obispos. Se necesitaba mostrar la fuerza del movimiento y eso fue lo que hicieron los miembros de la Liga. El llamado a realizar un boicot económico buscaba provocar una crisis económica y social. Tanto éste como la suspensión del culto iniciarían el 31 de julio, es decir, el día en que tomaba vigencia la Ley $\mathrm{Ca}$ lles. ${ }^{48}$ Ramírez decía que el éxito del boicot económico propició que el gobierno respondiera de manera agresiva: comenzó con el encarcelamiento de sacerdotes y la aprehensión de católicos que tuvieran propaganda del boicot. Conforme pasaba el tiempo, la situación se volvió desesperada para los católicos, quienes se vieron precisados a levantarse en armas contra el gobierno.

$\mathrm{La}$ inquietud que manifestaban algunos hombres acerca de la licitud del uso de las armas para defender a la religión fue solventada por Ramírez al construir una conversación entre Héctor y el padre

${ }^{48}$ Meyer, Cristiada, 1974, t. 2, pp. 289-293. La idea de realizar un boicot económico fue presentada el 7 de julio ante el Comité Episcopal. Esta idea fue aprobada el 14 de julio. El Comité Episcopal determinó el 24 de julio que también se iba a suspender el culto. Ramírez no exageraba cuando afirmaba que el boicot había tenido éxito. Aunque no logró desestabilizar por completo al país, sí se generaron serias repercusiones en la vida económica. El boicot se inscribió en un momento crítico de la economía mexicana. Ese año hubo malas cosechas, la política agraria no había dado resultados positivos, descendió la producción petrolera, bajó la venta de agave en el mercado internacional y hubo una baja internacional de dinero. El boicot tuvo mayor impacto en la provincia que en la ciudad de México. Éste propició cierta exasperación en el gobierno, pero no fue lo suficientemente fuerte para sentarlo a negociar. 
Arce. ${ }^{49}$ Esa conversación le permitió al autor introducir los argumentos que le permitieran

\section{La defensa}

del derecho a la resistencia heroica. ${ }^{50} \mathrm{Ra}-$ mírez destacaba que los católicos no intentaban realizar una revolución, sino, al contrario, como buenos cristianos, habían tolerado las injusticias en aras de la paz social. Sin embargo, sus enemigos no entendieron que ellos sólo buscaban el respeto a sus creencias. La constante agresión tenía que culminar con el levantamiento armado para defender sus principios. Y ese derecho nadie lo podía negar, pues tenía como base de sustento la lucha en contra del "injusto agresor" que encarnaba en la figura del tirano. Vale la pena recordar que David Ramírez pensaba que el gobernante tenía como principal misión realizar el bien común. ${ }^{51}$ Si no cumplía

${ }^{49}$ Meyer, Cristiada, 1974, t. 3, p. 15 . El encuentro entre Héctor y Gabriel Arce no resulta gratuito. Meyer dice que algunos jefes cristeros acudieron a consultar a sus párrocos en cuanto a la legitimidad del movimiento. La Liga no se lanzó a la lucha armada sin consultar la opinión del Comité Episcopal.

${ }^{50}$ Vegas, "Presentación", 1953, p. XXII. La presentación para la edición española es interesante. Vegas Latapie afirma que la doctrina que se defendía en Héctor era la que sostenía el magistral de la catedral de Salamanca, Castro Albarrán, acerca del derecho a la rebeldía. La razón por la que realizaba la comparación reside en el deseo del autor de dar un sustento más vigoroso a su argumento. Era más sencillo que el público se acercara a este libro si se amparaba bajo la opinión de un personaje importante.

${ }^{51}$ Palomar, Pensamiento, 1942, pp. 9-10. Palomar destacaba que "el principio de las gloriosas rebeldías" era necesario cuando el poder se ejercía de manera con esa tarea, entonces se convertía en un tirano. Si la tiranía era transitoria se podía soportar, en caso contrario se debería eliminar para no volverse cómplice de la obra nefasta. En el enfoque del autor, la tiranía encabezada por Calles carecía de legitimidad. Los intentos por conciliar a las partes fueron poco productivos. La prensa fue silenciada, las votaciones fueron amañadas, el plebiscito católico que reunió 2000000 de firmas fue ignorado. La intransigencia del gobierno negó cualquier posibilidad de solución pacífica. ${ }^{52}$

Así, el derecho divino a la "resistencia heroica" los amparaba para levantarse en contra de la tiranía. La época de la tolerancia y la resistencia pasiva daba paso a la época de la contienda directa. La utilización de medios armados se justificaba en tanto se trataba de una guerra justa. Ramírez sustentaba que el teólogo belga Genicot, el alemán Lehmkul, el austríaco Noldin, las Diez consideraciones utilísimas a los príncipes de Gerson, san Agustín, las Decretales de Juan XXII, La institutiones iuris naturalis de Meyer, el segundo libro de las Sentencias, la Summa teológica, la Secunda secundae, De Regimine principium de santo Tomás de Aquino y la Biblia autorizaban el uso de la resistencia armada en contra de los gobernantes "malvados". También mencionaba que el teólogo Meyer decía que ante la agresión y la injusticia era válido responder con la fuerza para rechazarlas. Aun en la misma Biblia se

ilegítima, al grado de que la sociedad y el Estado se conducían al camino del mal y de la destrucción.

${ }^{52}$ Meyer, Cristiada, 1973, t. 1, p. 70 . Meyer dice que el levantamiento armado mostró la falta de perseverancia y de imaginación política de la Liga. Así como un exceso de optimismo y su desconocimiento de las realidades de la guerra. 
podían encontrar argumentos que demandaban la guerra en contra del tirano. Eso lo sabía cualquier jurista católico y eran argumentos que se enseñaban en las cátedras. Sin embargo, el temor a las acciones del tirano había ocasionado que se escondieran los libros. A pesar de que esos libros tenían censura eclesiástica y, por lo mismo, podían ser utilizados sin ninguna restricción.

El uso de la guerra se convertía en un derecho válido para que los católicos recuperaran el bienestar común expresado en la caridad. ${ }^{53}$ Derecho que se debería transformar en un deber, puesto que el derecho eliminaba el compromiso personal con la causa; mas no sucedía lo mismo con el deber que se concebía como algo personal, ya que el deber se asociaba de manera indisoluble a la fe. Así, luchar por la fe era asumir el deber de todo cristiano. Nadie estaba exento de combatir. Todos deberían poner su contribución para apoyar a los combatientes, mismos que se encontrarían entre los hombres sanos de la sociedad, es decir, los hombres que combinaran la pobreza material, un espíritu sencillo y una limpieza de corazón. La muerte para ellos no representaría el sufrimiento eterno, pues la moral cristiana imponía el sacrificio de la vida misma en aras de la fe. Además, ellos estaban amparados bajo la doctrina del "heroísmo militar de la guerra", la cual decía que los que morían en defensa de la patria merecían el bien del cristianismo. Esos hombres se convertían en mártires de la fe. Por esta razón era

53 Torres, "Proyecto", 1998, pp. 113-114. La caridad se identificaba con el bien común. La paz como un acto propio y peculiar de la caridad tendía al respeto del orden, de la ley y del poder. Con la conjunción de estos elementos se llegaba al desarrollo del bien común. vergonzoso que no todos se hubieran levantado en armas para defender a la fe.

La pasividad no se justificaba cuando existían condiciones adversas al libre desarrollo de la patria. Es por ello que se consideraba un pecado no pelear contra el enemigo. La eliminación del tirano se volvía un asunto indispensable para lograr la salvación del pueblo. El autor mencionaba que la Biblia mostraba el ejemplo de Judith, que asesinó a un rey con la intención de liberar a su reino de la desgracia. Ahora les tocaba a los católicos mexicanos redimir al suyo. La muerte del tirano no se podía considerar como un pecado capital, pues no era el odio al prójimo lo que movía a realizar esta acción sino el odio al mal que lo animaba. Con la desaparición del tirano se lograba la libertad de una nación oprimida. ${ }^{54}$ Por el contrario, respetar su vida significaba la condena de los perseguidos. Por esta razón, los hombres que el día de ayer eran "mansos" y "piadosos" se deberían transformar en leones. No se podía tener piedad ante los opresores. La victoria de los defensores de la fe dejaría marcado un precedente: el nacimiento de un hombre nuevo, un hombre que encarnaría la necesidad espiritual extrema de un pueblo que bajo el dogma de la resistencia heroica conseguía sus ideales. Eso marcaría a las generaciones futuras y contribuiría a fortalecer a los católicos de México, de América Latina y del mundo entero.

Ramírez tenía la esperanza de que todos los hombres se convirtieran en sol-

${ }^{54}$ Ramírez, Guerra, 1935. Ramírez volvió a retomar este argumento en La guerra sintética. En esta novela vislumbraba la posibilidad de la muerte del tirano, único medio para acabar con las acciones que contrariaban el sentir del pueblo católico. 
dados de Dios y de la patria, dado que ésos podrían destruir las leyes contrarias al alma de la patria, con lo que se afianzaría el reinado del bien. Estas ideas lo llevaron a formular

\section{La utopia.}

de un nuevo orden en el que se inscribirían los católicos mexicanos, en el cual la Iglesia recuperaría sus atribuciones sobre las instituciones básicas de la sociedad como la familia, la escuela, la propiedad y la patria. Ramírez advertía que las disposiciones antirreligiosas gubernamentales habían ocasionado que la armonía familiar se alterara, que la escuela laica no contribuyera a la verdadera formación de los individuos, que la propiedad fuera arrebatada en aras de un falso agrarismo y que la patria se debatiera entre el bien y el mal. La victoria del movimiento significaría un cambio trascendental, que traería como fruto la salvación de México. Con la destrucción de los obstáculos que impedían la acción fecunda de la religión, se llegaría a un alto grado de desarrollo moral, intelectual, económico y social. En el nuevo orden, los hombres trabajarían en paz, la justicia los respetaría por igual, tendrían escuelas cristianas para sus hijos, sacramentos para sus almas, pan para los pobres, tierras para los campesinos y alegría general para los miembros de la sociedad. Sin embargo, el autor no se engañaba, pues sabía que el proyecto no se podía llevar a cabo mientras ellos no triunfaran.

Un triunfo que se les había negado por dos factores: la indecisión que mostraban los ricos para aportar recursos a la causa y por la negativa de una buena parte de los hombres católicos a levantarse en armas. Las condiciones se mostraban contrarias para el cumplimiento de la utopía. A pesar de los esfuerzos de los combatientes, el sueño utópico de Ramírez no se pudo cumplir.

\section{CONSIDERACIONES FINALES}

Vale la pena preguntarse si la novela histórica se puede considerar una fuente confrable de estudio. Ésta marca el punto de confluencia entre la historia y la literatu$\mathrm{ra}$, dos disciplinas que durante el siglo XIX perdieron el estrecho contacto que las caracterizaba, debido, en buena medida, a la pretensión de la historia de buscar un lugar dentro de la ciencia. Por esta razón, la historia desplazó todos aquellos elementos narrativos que no formaban parte de su esfera de acción. La separación de las dos esferas no fue aceptada por los literatos, quienes pugnaron porque sus interpretaciones fueran admitidas por los historiadores como una explicación más del comportamiento humano. Uno de los principales problemas que causaron la separación entre la historia y la literatura fue la apropiada delimitación de los campos de acción de las dos disciplinas. Daniel Aaron señala que mientras se mantuvieron en la esfera de la historia, los literatos fueron tolerados sin ningún problema; pero esa relación se rompió cuando éstos, y principalmente los novelistas, plantearon que ellos tenían una "sensibilidad histórica" más profunda de los acontecimientos. Por esta razón, ellos podrían dar una visión más completa de los sucesos. ${ }^{55}$

55 Aaron, "Verdades", 1993, pp. 66 y 68; Megged, Más, 1985, p. 23. 


\section{SECUENCIG}

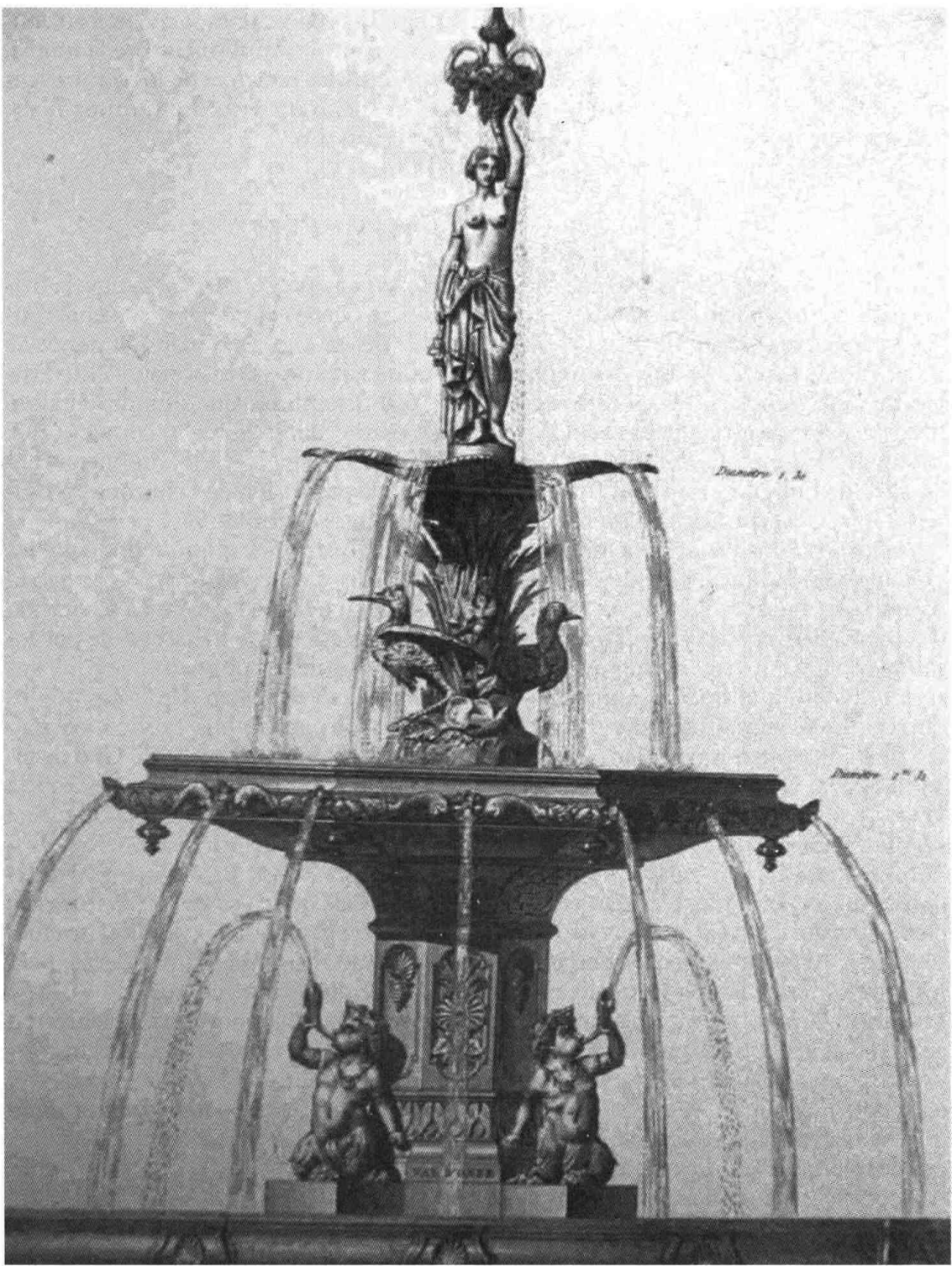


Esta postura no fue aceptada por los historiadores, quienes apreciaban a las novelas como arte de ficción y, por lo mismo, poco factibles de representar la realidad. La visión respecto a la relación entre las dos disciplinas ha cambiado en los últimos años. Los teóricos literarios se han encargado de mostrar que la literatura es un medio ideal para estudiar la realidad. Nahum Megged advierte que la literatura proporciona elementos para realizar estudios históricos, sociológicos, antropológicos y otros más, pues ésta no sólo refleja un mundo abstracto sino que también muestra mundos concretos de acción del hombre. Mundos que se recrean a través de la imaginación y que ayudan a expresar diversos aspectos de la realidad visible e invisible. Es decir, las acciones que se reproducen en una novela pueden ayudar a explicar una situación, cuando no se encuentran documentos que sustenten esa afirmación. Así, las intuiciones de los literatos se pueden considerar hipótesis acerca de la conducta humana y, en cierta forma, hasta se pueden tomar como conclusiones o juicios morales acerca de las acciones de los personajes que intervienen en ella. Carlos Rama ha mostrado que las novelas constituyen un material de estudio de primer orden, puesto que el elemento fundamental de la novela no es la acción imaginada sino la visión del escritor que se trasluce en ella. ${ }^{56}$

La ficción le sirve como un medio para expresar sus ideas. En este sentido, Celia Fernández menciona que la ficción se convierte en un espacio común para la historia y la literatura. La ficción novelesca no busca desplazar a la historia, ya que las

${ }^{56}$ Megged, Más, 1985, p. 14; Brushwood, Barbarie, 1988, p. 9; Berger, Novela, 1979, p. 283. dos persiguen fines diferentes, sino que la ficción al seguir una trama basada en la historia, tiende un puente que le permite hacer verosímil su relato y, de paso, resuelve el problema de la discrepancia entre la historia y la novela porque dota a lo imaginario de una semejanza con lo real. La noción de verosimilitud como espacio de acción común entre estas disciplinas contribuye a situar a la novela entre las formas de conocimiento. No se puede negar que la novela es un reflejo de la realidad e indaga en ella para acercarse a las actividades y acontecimientos que relata. Por ello es que los novelistas han incluido en sus relatos las instituciones, las clases y los procesos sociales que pueden ser identificados por el público. Los novelistas se benefician de la enciclopedia cultural de los lectores y adoptan "los sistemas ideológicos" en los que se concibe la relación entre el pasado y el presente. Por lo anterior, se puede concluir que la novela funciona como un documento histórico al combinar aspectos de la historia en la trama y porque aporta elementos de la visión y del momento en el que escribe el autor. ${ }^{57}$

Héctor se ha considerado una obra de poco valor literario e histórico. La severidad de las críticas ha ocasionado que no se adviertan dos particularidades interesantes. El deseo del autor de mostrar, por un lado, los fundamentos con los que se justifica el movimiento cristero y, por el otro, dibujar los valores humanos encarnados en los dos personajes principales: Héctor y Consuelo. David Ramírez consideraba que el mo-

5) Véanse Rama, Historia, 1975, pp. 30 y 44; Fernández, Historia, 1998, pp. 35 y 39; Barthes, Gnado, 1993, p. 39; Certeau, Historia, 1998, p. 54. 
vimiento cristero no fue producto de una rebelión injustificada. Al contrario, las condiciones históricas llevaron a los católicos a levantarse en defensa de su fe. Una fe que había sido mancillada por las botas de los militares revolucionarios. Los católicos habían resistido con estoicismo los ataques, pero la continua amenaza del Estado no les dejó otra alternativa. La lucha armada no sólo buscaba restaurar la religión, sino también tenía la pretensión de cambiar el orden de las cosas. El autor destacaba que la rebelión no fue producto de la agresión hacia la Iglesia, sino la conjunción de distintas situaciones contrarias a la población en general. Su argumentación intentaba validar la licitud del uso de las armas en contra de la tiranía. Calles era el tirano que oprimía sin tregua a los mexicanos.

Por ello era válido pelear para lograr el bien común. Ramírez advertía que el uso de las armas para defender la religión era un argumento que había sido defendido por los grandes teólogos de la cristiandad. Si ellos lo validaban, entonces no había razón para inferir un castigo a aquellos hombres que seguían este pensamiento. La utilización de alegorías es un rasgo que caracteriza a los novelistas de tema cristero. A través de éstas se buscaba mostrar los modelos ideales del hombre y de la mujer católicos. En la novela de David Ramírez, la mujer pierde su papel tradicional. Ella no es sólo una integrante más del relato, tiene su propia personalidad y eso le permite manipular las acciones a su favor. Los hombres y las mujeres adquieren la misma capacidad de decisión; sin embargo, las mujeres tienen la última palabra en el desarrollo de la novela. Un ejemplo de ello es Consuelo: su papel en el drama de la novela no se reducirá al de una simple espectadora de los eventos, sino que ella los provocará. Es un personaje activo en el transcurso de la novela. Resulta interesante destacar que Ramírez consideraba a Consuelo como la representación alegórica de la Iglesia. En el caso de Héctor, se retrata al hombre virtuoso y al dirigente que se lanza a la lucha para mostrar su rebeldía frente a los desmanes del gobierno.

El protagonista representa el brazo armado que peleará por los ideales del movimiento. El que Ramírez haya escogido el nombre de Héctor para su héroe central, responde a su interés de mostrar que en este personaje recaía el deber de defender a la Iglesia. Como el héroe homérico podría ser traicionado, pero siempre surgiría otro Héctor que continuaría la lucha que iniciaron otros. El protagonista es concebido por Ramírez como el cristero ideal. Su matrimonio con Consuelo refleja la concordia existente entre la Iglesia y los cristeros. Al fin y al cabo, la protagonista se manifiesta como el alivio a los pesares; Héctor, el cristero, podía encontrar una tregua y un descanso de sus aflicciones en el seno de Consuelo. La unión de los dos llevaría a la creación de un nuevo orden. Además, Nadia Julien señala que el Héctor homérico ha sido considerado el símbolo del amor filial, del amor conyugal y de la generosidad. Estos tres elementos se perciben en el héroe que retrata Ramírez. Un héroe que además responde al tipo de personaje de la novela romántica clásica, pues es un catalizador de las fuerzas históricas y las tendencias sociales más que un agente de cambio. ${ }^{58}$ Una de las acusaciones más

${ }^{58}$ Julien, Enciclopedia, 1997, p. 187; Pons, Memorias, 1996, p. 49. 
graves que se le han prodigado a la novela de tema cristero es que ella ha contribuido a la deformación de los sucesos que relata.

David Ramírez no ha escapado de esta recriminación. Se menciona que su novela toma partido por los cristeros, razón por la cual presenta sus acciones como gloriosas, en contraposición a los actos militares. En su narración se considera que el asalto al tren de Guadalajara es una acción valiente de los cristeros, pero no se dice nada acerca de la mortandad causada en la refriega. De hecho, Ramírez afirma que el tren no iba custodiado. El hecho histórico se toma como punto crucial en la historia, pues Héctor tenía que tomar una decisión acerca de la conducta que iba a seguir. La novela relata un final feliz. Héctor salva a su amada y los cristeros obtienen las armas para pelear. Es cierto que el autor se apartó de la versión histórica, pero debemos recordar que una de las funciones de la novela histórica no es volver a contar los hechos de la historia, sino crear una experiencia particular a través de la ficción. ${ }^{59}$ Más allá de retratar el evento, buscó recrear una sensación entre sus lectores. El heroísmo y la piedad conjugados en una misma acción. Aunque Héctor no es la mejor novela de tema cristero, sí es la única que presenta argumentos para defender al movimiento.

Quizá se lo puede criticar por su composición estilística o por su visión parcial del movimiento, empero lo que no se le puede dejar de reconocer a David Ramírez es su valentía para dejar un testimonio fehaciente del hecho que le tocó vivir.

${ }^{59}$ Brushwood, México, 1973, p. 37.

\section{BIBLIOGRAFÍA}

-Aaron, Daniel, "Las verdades de la ficción histórica", Facetas, núm. 100, 1993, Washington, pp. 62-70.

-Bailey, David C., ; Viva Cristo Rey! The Cristero Rebellion and the Church State Conflict in México, University of Texas Press, Texas, 1974.

-Barquín y Ruiz, Andrés, José María González y Valencia. Arzobispo de Durango, Jus, México, 1967 (México Heroico, 75).

-Barthes, Roland, El grado cero de la escritura seguido de nuevos ensayos críticos, Siglo XXI Editores, México, 1993.

-Bellenger, Lionel, La persuasión, FCE, México, 1989 (Colección Popular, 430).

- Berger, Monroe, La novela y las ciencias sociales. Mundos reales e imaginados, FCE, México, 1979 (Breviarios, 280).

-Blancarte, Roberto, "El contexto socio-histórico en el proceso de las reformas constitucionales en materia religiosa" en Patricia Galeana (comp.), Relaciones Estado-Iglesia. Encuentros y desencuentros, AGN-Secretaria de Gobernación, México, 1999, pp. 249-258.

-Brushwood, John S., México en su novela. Una nación en busca de su identidad, FCE, México, 1973 (Breviarios, 230).

- La barbarie elegante. Ensayos y expieriencias en torno a algunas novelas bispanoamericanas del siglo XIX, PCE, México, 1988 (Tierra Firme).

-Carballido, Emmanuel, Protagonistas de la literatura mexicana, SEP/Ediciones del Ermitaño, México, 1986 (Lecturas Mexicanas, 48).

-Certeau, Michel de, Historia y psicoanálisis. Entre ciencia y ficción, UIA/ITESO México, 1998.

-Dessau, Adalbert, La novela de la revolución mexicana, FCE, México, 1972 (Colección Popular, 117).

-Dooley, Francis Patrick, Los cristeros, Calles y el catolicismo mexicano, SEP, México, 1976 (Sepsetentas). 
- Diccionario Porrúa de Historia, Biografía y Geografia de México, Porrúa, México, 1955, t. II

-Fernández Prieto, Celia, Historia y novela: poética de la novela bistórica, EUNSA, Pamplona, 1998 (Colección Anejos de Rilce, 23).

-Galeana, Patricia (comp.), Relaciones EstadoIglesia. Encuentros y desencuentros, AGN-Secretaria de Gobernación, México, 1999.

-González, Fernando M., Matar y morir por Cristo Rey. Aspectos de la cristiada, IIS-UNAM/Plaza y Valdés, México, 2001.

-Gutiérrez Casillas, José, Historia de la Iglesia en México, Porrúa, México, 1993.

-Julien, Nadia, Enciclopedia de los mitos, Océano/Robin Book, México, 1997.

-MacGregor, Josefina, “Anticlericalismo constitucionalista" en Patricia Galeana (comp.), Relaciones Estado-Iglesia. Encuentros y desencuentros, AGN-Secretaría de Gobernación, México, 1999, pp. 163-182.

-Magaña Esquivel, Antonio, La novela de la revolución, INEHRM, México, 1964, t. 1 (Biblioteca del INEHRM, 33).

- La novela de la revolución, INEHRM, México, 1965, t. 2 (Biblioteca del INEHRM, 39).

-Megged, Nahum, Más allá de las palabras. La literatura bispanoamericana como expresión y como idea, Colmex, México, 1985 (Jomadas, 108).

-Meyer, Jean, La cristiada. La guerra de los cristeros, Siglo XXI Editores, México, 1973, t. 1. - La cristiada. El conflicto entre la Iglesia y el Estado, 1926-1929, Siglo XXI Editores, México, 1974, t. 2.

- La cristiada. Los cristeros, Siglo XXI Editores, México, 1974, t. 3.

y Juan José Doñan (selec. y pról.), Antología del cuento cristero, Secretaria de Cultura de Jalisco, Guadalajara,1993.

-Morton Rand, F., Los novelistas de la revolución mexicana, Cultura, México, 1949.

-Olivera de Bonfil, Alicia, La literatura cristera, INAH, México, 1970 (Divulgación, Serie Historia).
-Palomar y Vizcarra, Miguel, El pensamiento cristero, s. e., Colima, 1942.

-Perus, Françoise, El realismo social en perspectiva, IIS-UNAM, México, 1995.

-Pons, María Cristina, Memorias del olvido. Del Paso, Garcia Márquez, Saer y la novela histórica de fines del siglo XX, Siglo XXI, México, 1996.

-Rama, Carlos, La historia y la novela, Tecnos, Madrid, 1975.

-Ramírez, David (Jorge Gram), La guerra sintética, RexMex, México, 1935.

- Héctor: novela histórica cristera, Jus, México, 1953.

-Rius Facius, Antonio, De don Porfirio a Plutarco. Historia de la ACJM, Jus, México, 1958. , Méjico cristero. Historia de la ACJM, 1925 a 1931, Patria, México, 1960.

-Romero, Laura Patricia, "Presentación" en Laura Patricia Romero y Wolf gang Vogt (comps.), Literatura de las revoluciones en México, Centro Universitario de Ciencias sociales y $\mathrm{Hu}-$ manidades-Udeg, Guadalajara, 1996.

-Sefchovich, Sara, México: país de ideas, país de novelas. Una sociología de la literatura mexicana, Grijalbo, México, 1987 (Enlace. Cultura y Sociedad).

-Torres Meza, Martha Patricia, "El proyecto social y político de la Liga Nacional Defensora de la Libertad religiosa, 1925-1929", tesis de maestría, Instituto Mora, México, 1998.

-Vaca, Agustín, Los silencios de la bistoria: las cristeras, El Colegio de Jalisco, Guadalajara, 1998.

-Valenzuela Rodarte, Alberto, Historia de la literatura en México, Jus, México, 1961.

-Vegas Latapie, Eugenio, "Presentación" en David Ramírez (Jorge Gram), Héctor: novela bistórica cristera, Jus, México, 1953, pp. IX-Xxv.

-Villegas, Gloria, "Estado e Iglesia en los tiempos revolucionarios" en Patricia Galeana (comp.), Relaciones Estado-Iglesia. Encuentros y desencuentros, AGN-Secretaria de Gobernación, México, 1999, pp. 183-203. 